\title{
The SARS-COV2 (COVID-19) Pandemic: What Clinicians should Know
}

\author{
Mayssa A. Saeed ${ }^{1}$, Tarik Ibrahim Zaher ${ }^{1}$, Soha E Khorshed ${ }^{1}$, Mohamed \\ Saraya $^{1}$, Taghrid Mohamed Mahmoud ${ }^{1}$, Mohamed H Emara ${ }^{2}$, Aya M. \\ Mahrous $^{2}$, Nabila Hassan Ahmed ${ }^{1}$, Fathia M. Khattab ${ }^{3}$, Mona Ahmed \\ Abdelmaksoud ${ }^{1}$, Emad H Emara ${ }^{4}$, Ahmed Nasr Eldin Bekhit ${ }^{1}$, Ahmad \\ Khaled $^{1}$, Mohammed Eleda ${ }^{1}$, Nadien K Fahim ${ }^{5}$ \\ ${ }^{1}$ Department of Tropical Medicine, Faculty of Medicine, Zagazig University, Zagazig, \\ Egypt. \\ ${ }^{2}$ Department of Hepatology, Gastroenterology and Infectious Diseases, Faculty of \\ Medicine, Kafrelshiekh University, Kafr Elshikh, Egypt. \\ ${ }^{3}$ Department of Dermatology, Venereology and Andrology, Faculty of Medicine, \\ Zagazig University, Egypt. \\ ${ }^{4}$ Department of Radiology, Faculty of Medicine, Kafrelshiekh University, Kafr Elshikh, \\ , Egypt. \\ ${ }^{5}$ Clinical Program, Faculty of Pharmacy, Zagazig University, Zagzig, Egypt.
}

Corresponding Author Tarik I Zaher

Mobile:

$+201001855393$

E mail:

tareqzaher@gmail.com

Key words:

SARS-CoV-2, COVID-

19, Pandemic,

Pneumonia, WHO
In late 2019, a novel coronavirus, now designated SARS-CoV-2, emerged and was identified as the cause of an outbreak of acute respiratory illness in Wuhan, a city in China, named as COVID-19. Since then the waves of the virus exponentially hit many countries around the globe with high rates of spread associated with variable degrees of morbidity and mortality. The WHO announced the pandemic state of the infection in March 2020 and by June 1st 2020 more than 6 million individuals and more than 370 thousands case fatalities were documented worldwide. In this article, we discussed many aspects regarding this emerged infection based on the available evidence aiming to help clinician to improve not only their knowledge but also their practices toward this infection.

\section{INTRODUCTION}

In late 2019, a novel coronavirus, now designated as SARS-CoV-2, was identified as the cause of an outbreak of acute respiratory illness in Wuhan, a city in China [1]. The World Health Organization (WHO) named the disease COVID-19 in February 2020. Since the first reports of COVID-19, infection has spread in waves prompting the WHO to declare a public health emergency in late January 2020 and characterize it as a pandemic in March 2020. By June 1st 2020 more than $6,000,000$ confirmed cases worldwide were reported with more than 370,000 deaths $[\mathbf{2 , 3}]$.

\section{VIROLOGY}

Four genera of coronaviruses (CoV) were identified as $\alpha, \beta, \gamma$ and $\delta \mathrm{CoV}$. $\mathrm{A}$ and $\beta \mathrm{CoV}$ tend to infect mammals while $\gamma$ and $\delta \mathrm{CoV}$ can infect birds. COVID-19 is one of the Beta corona viruses. They include; Middle-East Respiratory Syndrome (MERS-CoV), Severe Acute Respiratory Syndrome coronavirus (SARS-CoV) and Severe Acute Respiratory Syndrome coronavirus 2 (SARS-CoV2) the causative agent of COVID-19 pandemic $[4,5]$. HKU1 and OC43 are also members of Beta corona viruses [5-7]. Alpha corona viruses include NL63 and 229E strains of HCoVs. COVID-19 has positivesense single-stranded RNA (+ss RNA). The virion of COVID-19 is about 50-200 $\mathrm{nm}$ in diameter. 
There are 2 types of proteins characterizing HCoVs; structural [Nucleocapsid (N), Spike (S), Matrix (M) and Envelope (E)], and nonstructural proteins [nsp12 and RNA dependent RNA polymerase] [7-8]. Cell entry of SARS$\mathrm{CoV}-2$ is facilitated by the spike protein which is priming by serine 2 (transmembrane protease ;TMPRSS2) [7,8].

After a SARS-CoV-2 virion attaches to a target cell, the cell's protease (TMPRSS2) cuts open the spike protein of the virus, exposing a fusion peptide. The virion then releases RNA into the cell, forcing the cell to produce copies (Figure 1) of the virus that are disseminated to infect more cells [9].

Phylogenetic analysis of 103 strains of SARSCoV-2 from China, revealed two different types of SARS-CoV-2, designated type L (accounting for 70 percent of the strains) and type $S$ (accounting for 30 percent). The $\mathrm{L}$ type predominated during the early days of the epidemic in China, but accounted for a lower proportion of strains outside of Wuhan than in Wuhan. The clinical implications of these findings are uncertain [10].

\section{PATHOGENESIS}

The pathogenesis of COVID-19, cannot be caught on, many mechanisms were adopted by the similarity of the clinical presentation to that of SARS and MERS-COV.

\section{Receptor interaction and cell entry:}

The main site of viral replication is the mucosa of the upper respiratory tract followed by affection of the lower respiratory tract and gastrointestinal tract. This may be explained by the presence of ACE2 receptors at these sites [911].

Viral spike (S) protein plays a major role in penetration of target cells [12]. The outer $S$ protein binds to its specific receptors e.g. ACE2 and CD209L for SARS [13,14], DPP4 for MERS [15], ACE2 for SARS-CoV-2 [16]. Membrane infusion is enhanced by abnormal two-step furin activation in MERS-CoV [17]. SARS-CoV entry mediated by both membrane fusion and endocytosis $[18,19]$. After entry into the cells, the viral single stranded RNA passed to the cytoplasm and viral replication is only possible after its translation into structural proteins and polyproteins [20]. The envelope glycoproteins are inserted into the endoplasmic reticulum membrane, and formation of the nucleocapsid is done (Figure 1) by the union of viral genome and polyprotein. Finally, release of the virus occurs by fusion of the vesicles containing the virus with the plasma membrane [12].

\section{Antigen presentation:}

After cell entry by the virus, presentation of its antigens (Ags) to the antigen presenting cells occurs. Major histocompatibility complex is responsible for presentation of viral antigenic peptide followed by viral recognition by specific $\mathrm{T}$ lymphocytes. MHC I molecules and to lesser extent MHC II are responsible for antigen presentation of SARS-CoV [21]. Whereas, MHC II molecules, are responsible for antigen presentation in MERS-COV [22].

\section{Humoral and cellular immunity}

Both humoral and cellular immune responses are stimulated by antigen presentation. In SARSCoV-2-infected patients, although the number of cytotoxic and helper $\mathrm{T}$ cells in the circulation are significantly reduced, it is excessively activated, as evidenced by high proportions of HLA-DR (CD4 3.47\%) and CD38 (CD8 39.4\%) doublepositive fractions [23].

\section{Cytokine storm in COVID-19:}

ARDS is the believed fatal sequel of coronavirus. Occurrence of cytokine storm is a major mechanism for ARDS. Cytokine storm is aggressive systemic inflammatory response characterized by the release of excessive amounts of pro-inflammatory cytokines (IL-6, IL-12, IL-18, ,IFN- $\alpha$, IFN- $\gamma$, TNF- $\alpha$, , etc.) and chemokines by immune effector cells [24]. The final consequence is ARDS and multiorgan failure, and death in severe cases. A recent multicenter study of confirmed COVID-19 cases in Wuhan, China showed elevated ferritin (mean $1297.6 \mathrm{ng} / \mathrm{ml}$ in non survivors vs $614.0 \mathrm{ng} / \mathrm{ml}$ in survivors; $p<0 \cdot 001)$ and IL-6 $(\mathrm{p}<0 \cdot 0001)$, suggesting that mortality might be due to virally driven hyper inflammation [23].

\section{Coronavirus immune evasion:}

Corona viruses develop multiple mechanisms to avoid recognition by the host immune response. The most important one is formation of thick wall vesicles that lack protein recognized receptors (PRRs), thereby escaping the immune detection [25]. Other mechanisms including 
inhibition of IFN-I pathway [26], and antigen presentation.

\section{ACEI and ARBs drugs: harmful or helpful?}

There is a controversy about whether angiotensin converting enzyme (ACE) inhibitors and angiotensin receptor blockers (ARBs) may increase susceptibility to the COVID-19 virus infection or not. The concern of increase the susceptibility of COVID-19 infection is due to observation of increased morbidity and mortality of COVID-19 in patients with hypertension treated with ARBs or ACEI [27].

The use of ACEIs and ARBs may increase expression of ACE2 and increase the susceptibility to viral host cell entry and replication. ACE2 has a broad expression in the body with strong expression in the heart, gastrointestinal system, kidney, and type II alveolar cells in the lungs. This is supported by the evidence that ACE2 has been shown to be a co-receptor for viral entry for SARS-CoV-2 [28].

In animal model, ACE2 down regulation by SARS-CoV, lung injury was improved by treatment with ARBs. These preclinical data suggest that increasing ACE2 expression can decrease SARS-CoV-2-induced lung injury, however, there is no direct clinical evidence that has proven ARBS to be an effective treatment for viral-induced lung injury $[29,30]$.

\section{Coagulopathy and Antiphospholipid Antibodies in Patients with COVID-19:}

Recent literature describe clinically significant coagulopathy, thrombocytopenia, an elevated prothrombin time and partial thromboplastin time, and elevated levels of fibrinogen and Ddimer in critically ill patients with COVID-19 [31]. Serologic testing showed the presence of anticardiolipin IgA antibodies as well as anti- $\beta 2$ glycoprotein I IgA and IgG antibodies in some cases [31]. Endothelial damage leading to subsequent clotting and diffuse thrombosis has been proposed as the mechanism of multiple organ affection. These data were emphasized by results of autopsies from both China and Europe and consequently anti-coagulants were added to the treatment regimen of ill COVID-19 patients with promising results. Furthermore, the unexplained sudden hypoxia noticed among stable COVID-19 patients would be explained by this diffuse thrombotic state besides the dissociation of hemoglobin noticed among those patients. Recent studies reported significant deposits of terminal complement components C5b-9 (membrane attack complex), C4d, and mannose binding lectin (MBL)-associated serine protease (MASP)2, in the microvasculature, consistent with sustained, systemic activation of the alternative and lectin-based complement pathways in many tissues including the lung and the skin [32-34].

\section{MODES OF TRANSMISSION}

Bat, was suggested to be a natural reservoir host of the virus where it is transmitted to humans by an unknown intermediate host. Like SARS-Co, it is well established that COVID-19 uses angiotensin-converting enzyme 2 (ACE2) receptor to infect humans [29-33]. Following emerging of COVID- 19 in Wuhan, China a seafood market was suspected to be the origin of infection but without a strong evidence $[35,36]$. Phylogenetic analysis showed that many species have a possibility of being an alternative intermediate host, such as pangolin, snacks and turtles [37].

The most impressive character of COVID-19 is the human to human transmission. This usually occurs between family members, relatives and friends who had intimate contact with patients or incubation carriers [38]. Large droplet during sneezing or coughing is the main method of transmission of COVID- 19 [39]. Transmission between healthcare workers was reported in $3.8 \%$ of COVID-19 patients as reported by National Health Commission of China on $14^{\text {th }}$ February 2020. Another mode of transmission is direct contact with the intermediate animal host or consumption of wild animals that was suggested to be the main mode of transmission of COVID-19. However, a great debate is still present about the source and routine mode of transmission of infection [40]. Patients remain infectious so long the symptoms are presents and even through the clinical recovery. Some persons are even super spreaders such as those attending conferences. Infection is acquired through inhalation of the infected droplet or by touching a contaminated surface and then touching the nose, mouth or eyes. The virus was also discovered in stool with the potential contamination of water resources and feco- oral transmission [41]. Viral load in the nasal cavity is more than that in the throat but there is no 


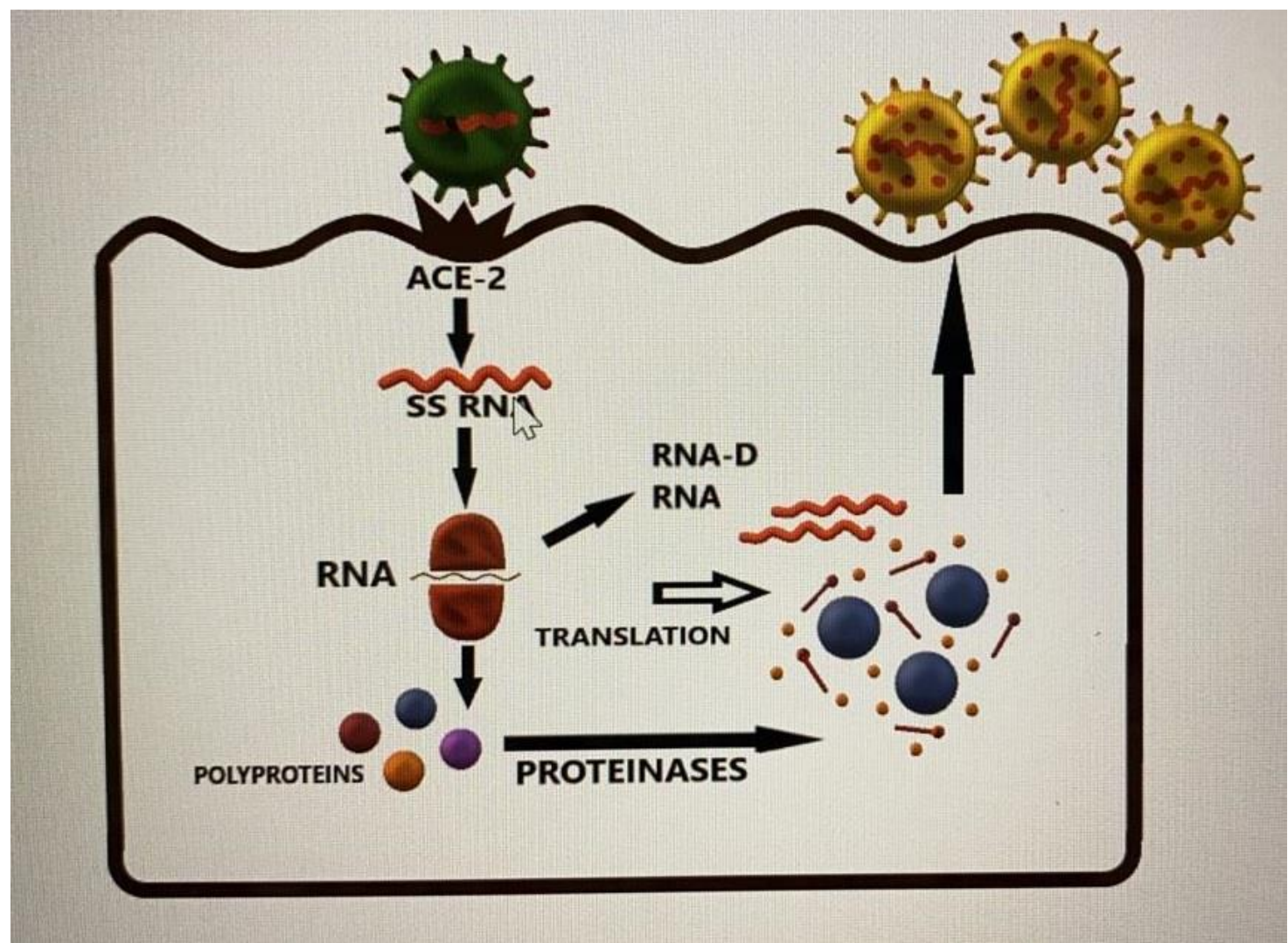

Figure 1: Pathogenesis of the infection. Note that the virus enters the cells through Angiotensin converting enzyme (ACE) 2 receptors.

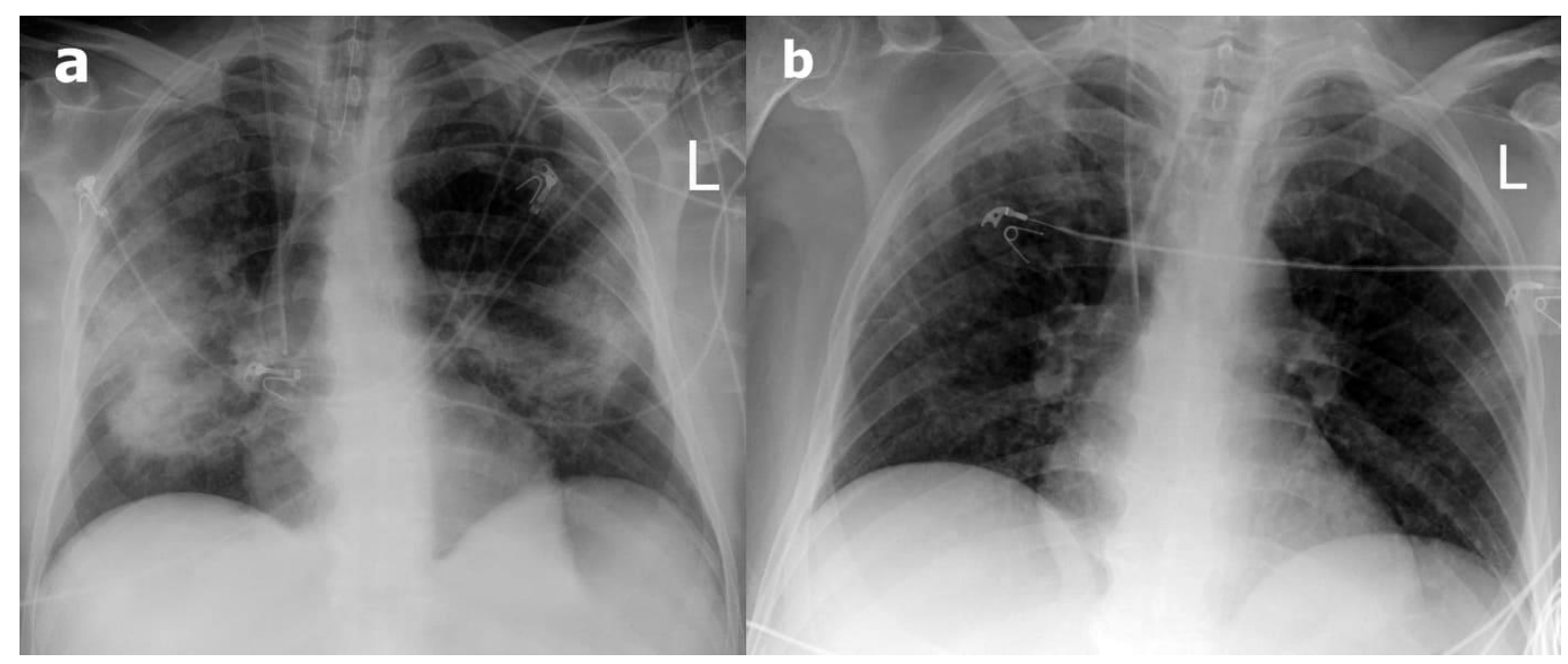

Figure 2: Chest X-ray of COVID-19 patient

(a) Chest radiography (AP view) at day of admission, showing bilateral and peripheral alveolar consolidations in lower and middle lung zones, more prominent in the right lung, no pleural effusion or hilar lymphadenopathy.

(b) Chest radiography (AP view) three weeks later showing improvement of the alveolar consolidations together with improvement of the clinical condition of the patient. 
difference between symptomatic and asymptomatic cases [42]. The infected droplet can spread within 1-2 meters to settle on surfaces where the virus can stay viable in convenient atmospheric conditions but can be destroyed within a minute by the usual disinfectants [43]. Vertical transmission is not suspected but postnatal neonatal infection of neonates was described [44]. Hospital acquired transmission is suggested to be $41 \%$ of patients [45]. The incubation period of the disease ranges from 214 days with average of 5 days. The basic case reproduction rate is 2- 6.47 [46] while that for SARS was 2 and for pandemic flu H1N1 2009 is 1.5 [47].

\section{CLINICAL FEATURES}

\section{Spectrum of illness severity:}

The spectrum of symptomatic infection ranges from mild to critically severe infections. The majority of infections are mild $[\mathbf{4 8 , 4 9 ]}$. The Chinese Center for Disease Control and Prevention reported an estimation of disease severity as follow [50]:

- Mild (no or mild pneumonia) was reported in $81 \%$ of cases.

- Severe disease (e.g., with dyspnea, hypoxia, or $>50 \%$ lung involvement on imaging within 24 to 48 hours) was reported in $14 \%$ of cases.

- Critical disease (e.g., with respiratory failure, shock, or multiorgan dysfunction) was reported in $5 \%$ of cases.

\section{Risk factors for severe illness:}

Severe illness mainly occurs in adults with advanced age or underlying medical comorbidities. Comorbidities that associated with severe illness and mortality include

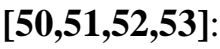

- Cardiovascular disease

-Diabetes mellitus

-Hypertension

-Chronic lung disease

-Cancer

-Chronic kidney disease

In addition the Centers for Disease Control and Prevention (CDC) includes immunecompromising conditions, severe obesity (body mass index $\geq 40$ ), and liver disease as potential risk factors for severe illness [54].

\section{Asymptomatic infections}

Asymptomatic infections have also been described [48]. In a COVID-19 outbreak on a cruise ship, approximately $17 \%$ of the population on board were positive for SARSCov-2 and about half of the 619 confirmed COVID-19 cases were asymptomatic at the time of diagnosis [55].

Patients with asymptomatic infection may have objective clinical abnormalities [56,57]. In a study comprised 24 patients with asymptomatic infection who all underwent chest computed tomography (CT), $50 \%$ had patchy shadowing or typical ground-glass opacities. Few days after diagnosis five patients developed low-grade fever, with or without other typical symptoms [56].

\section{Clinical manifestations:}

\section{Initial presentation}

There are no specific clinical features that can distinguish COVID-19 from other viral respiratory infections. The most common clinical features in a study were [58]:

- Fever in 99 percent

- Fatigue in 70 percent

- Dry cough in 59 percent

- Anorexia in 40 percent

- Myalgias in 35 percent

- Dyspnea in 31 percent

- Sputum production in 27 percent

Fever might not be a universal finding. In one study, it was reported in all patients, but about 20 $\%$ of them had a low grade fever $<38^{\circ} \mathrm{C}$ [59]. In another study of 1099 patients from Wuhan and other areas in China, fever was present in only 44 $\%$ of patients on admission [60].

Patients with COVID-19 may has smell and taste disorders (e.g., anosmia and dysgeusia) as common symptoms. In a study carried on 59 patients with COVID-19 in Italy, $34 \%$ had either a smell or taste aberration and 19\% had both [61]. In addition gastrointestinal symptoms (e.g., nausea and diarrhea) have been reported; and in some patients, they may be the presenting complaint [62].

Kidney injury(direct effect of the virus or late due to cytokine storm) as well as conjunctivitis are also noticed in COVID 19. 


\section{DIAGNOSIS}

\section{Clinical suspicion and criteria for testing:}

Suspected COVID 19 case: The case definition should be considered when, there are acute symptoms suggesting respiratory tract infection (such as at least one of the following: fever, cough, dyspnea) plus no other cause explaining the clinical presentation plus a history of residence or travel to an endemic area during the last 2 weeks before being symptomatic; or close contact with a confirmed or probable COVID-19 case during the last 2 weeks before being symptomatic. Severe acute respiratory illness requiring hospitalization without any other cause explaining the clinical presentation can be considered as a suspected case also [63].

Close contact, is defined as a person living in the same house with a confirmed case or having had direct physical contact with confirmed case or face-to-face contact or being in a closed environment within 2 meters for more than 15 minutes with a confirmed case or having unprotected direct contact with infectious secretions of a confirmed COVID-19 case. Also a healthcare personnel and laboratory worker dealing with confirmed case without using personnel protective equipment (PPE) is considered a close contact [64].

Although, suspected cases should undergo testing for COVID 19, they don't need emergency care and should be encouraged to call prior to presenting to a health care facility for evaluation although they should perform strict home isolation precautions. Many patients can be evaluated regarding the need for testing over the phone. The diagnosis cannot be definitively made without microbiologic testing, but limited capacity may preclude testing all patients with suspected COVID-19.

Laboratory findings are usually nonspecific. There is normal leucocytic count or mild leucopenia. Lymphopenia is common; a decrease in the lymphocytes below one thousand commonly occur in severe disease. There is normal platelet count or mild thrombocytopenia. The ESR and CRP usually increase, on the other hand procalcitonin level is within the normal range. Procalcitonin increase indicates a bacterial co-infection and need for ICU. Other lab markers like liver enzyme, coagulation profile, kidney function, LDH, CPK and D-dimer, serum ferritin may increase and high levels of previous laboratory marker commonly occur in severe disease [65].

Wang et al., [45-57] and US CDC states that collecting the upper respiratory nasopharyngeal swab have more yielding results than oropharyngeal (OP) one. Induction of sputum collection is not recommended [66]. Swab specimens should be collected in a suitable viral transport medium. Bronchoscopy and bronchoalveolar lavage can produce an infectious aerosol which increased risk of transmit infection healthcare workers [67]. All respiratory specimen collection procedures should be done in negative pressure rooms. Additional specimens (e.g., blood, stool, urine) can also be collected to rule out alternative/supportive diagnosis.

During early infection, nasopharyngeal specimens may give false negative results; so bronchoscopy may be used to collect a deeper specimen. On the other hand, COVID-19 testing can be repeated because over time, the probability of the COVID-19 being present in the nasopharynx raises. Saliva specimens testing were positive in some cases, suggesting it is a promising non-invasive method for monitoring, diagnosis and infection control in COVID-19 infections [68]. The percentage of positive testing in a specimen differs according to the site of the specimen.

Regarding SARS-CoV-2, Real-time reverse transcription polymerase chain reaction (RTPCR) of viral nucleic acid is considered the diagnostic reference standard [66]. A positive test for SARS-CoV-2 generally confirms the diagnosis of COVID-19, although false-positive tests are possible. Results are generally available within a few hours to 2 days. The US CDC developed a PCR Diagnostic Panel for diagnosis and detection of COVID-19 [69]. Three separate PCR reactions target the $\mathrm{N}$ gene. One primer/probe set detects all beta corona viruses, while 2 sets are specific for COVID-19. All three measurements must be positive to confirm COVID-19 diagnosis [70]. For safety reasons, viral culture should not be routinely done for suspected SARS-CoV-2 patients [71].

Regarding serologic tests, using lateral flow immuno-chromatography technique, qualitative rapid test detects $\operatorname{IgG}$ and $\operatorname{IgM}$ antibodies to COVID-19 in blood, serum and plasma samples has been approved by the Food and Drug Administration . The IgM-IgG combo assay is 


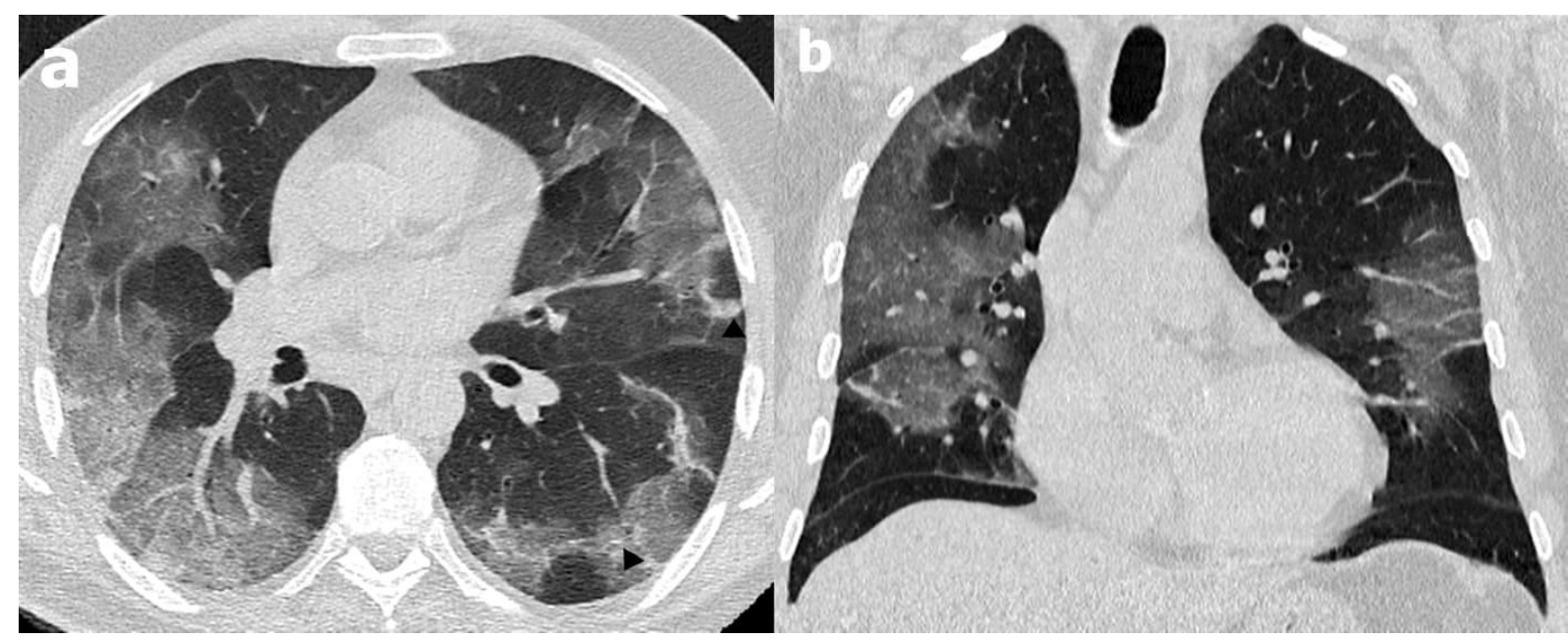

Figure 3: Images in an 83-year-old man who presented with fever, cough, and dyspnea. The polymerase chain reaction assay for the novel coronavirus (SARS-CoV2) was positive one week later.

(a) Axial CT chest at day of admission, showing bilateral multifocal peripheral sub-pleural ground glass opacities with peri-lobular opacities mainly in lower lung lobes which is classical for COVID-19.

(b) Coronal CT scan showing the peripheral sub-pleural distribution of the ground glass opacities in both lungs with more affection of the right lung.

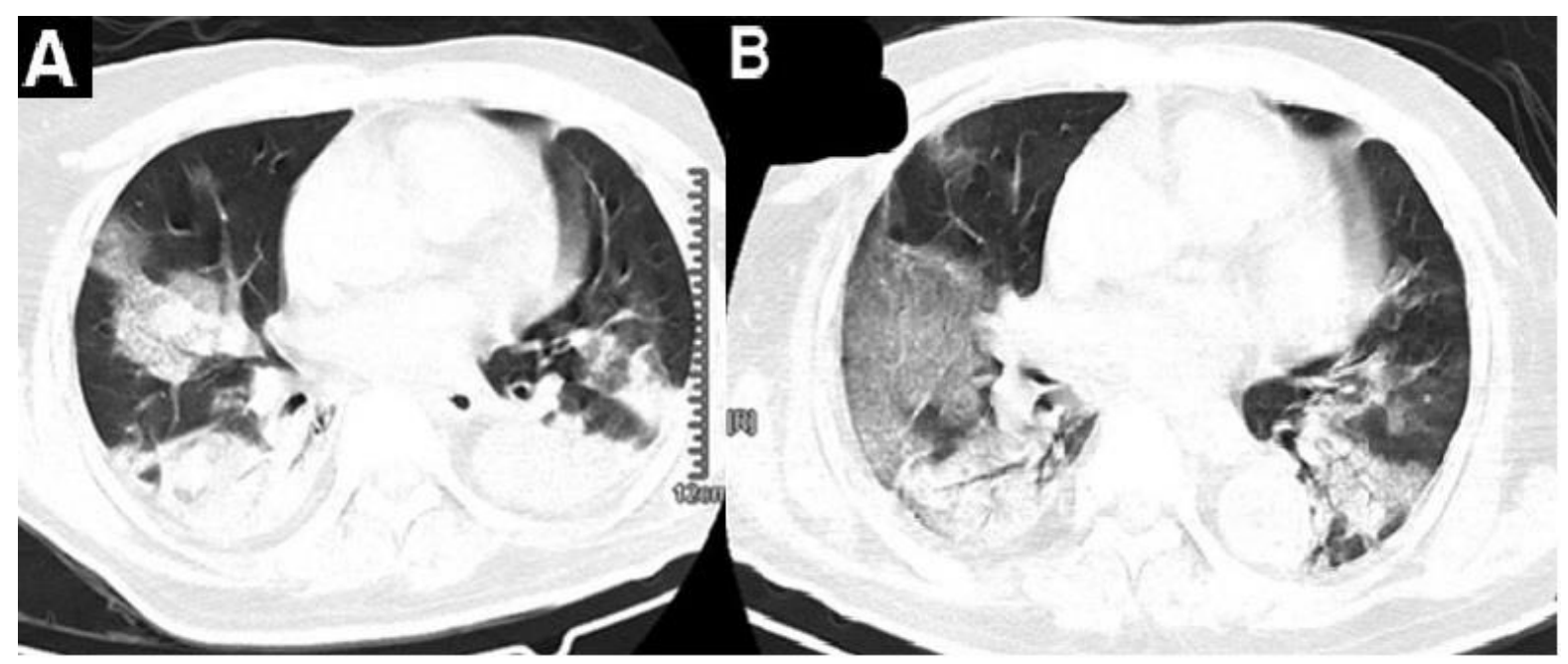

Figure 4: A 62-yr-old male with confirmed COVID-19 required endotracheal intubation and invasive mechanical ventilation. The chest computed tomography scan suggested that, compared with that before intubation (A), the pulmonary disease had progressed 3 days after intubation (B). This progression is thought to be from the disease itself rather than from the invasive ventilation technique. 
more sensitive than single $\operatorname{IgM}$ or $\operatorname{IgG}$ test. It could be considered for rapid screening of COVID-19. The obtained sample form a suspected COVID 19 case should be also investigated for other pathogens causing the same clinical picture. For antibodies to appear in the blood a period of 3-5 days after exposure to the virus needs to be lapsed. Furthermore, false negative cases are not uncommon besides the need to confirm positive cases by PCR. Most patients have detectable IgG antibodies by day 14 following symptom onset, and the likelihood of detection increases over time. In studies, antibody tests that detected both IgG and IgM were positive in $90 \%$ of symptomatic individuals by days 11-24 [2-73].

Table (1): Diagnostic Test sensitivity in Days after Symptom Onset.

\begin{tabular}{|l|c|c|c|}
\hline & \multicolumn{3}{|c|}{ Days after Symptoms onset } \\
\hline $\begin{array}{l}\text { SARS COV- } \\
\text { 2 Test }\end{array}$ & $1-7$ & $8-14$ & $15-39$ \\
\hline $\begin{array}{l}\text { RNA by RT- } \\
\text { PCR }\end{array}$ & $67 \%$ & $54 \%$ & $45 \%$ \\
\hline $\begin{array}{l}\text { Total } \\
\text { antibody }\end{array}$ & $38 \%$ & $90 \%$ & $100 \%$ \\
\hline Ig M & $29 \%$ & $73 \%$ & $94 \%$ \\
\hline Ig G & $19 \%$ & $54 \%$ & $80 \%$ \\
\hline
\end{tabular}

Chest CT is suggested as an important tool for SARSCoV-2 infection diagnosis especially in patients with false negative RT-PCR results, with sensitivity up to $98 \%$ [74]. Typical X-ray (Figure 2) and CT (Figure 3) imaging findings, including, bilateral ground glass opacities, which are multiple, patchy, sub-segmental or segmental lung consolidation (classified as "paving stonelike" changes by fine-grid or small honeycomblike thickening of interlobular septa) particularly in the middle and lower lobes [75].

Regarding atypical X-ray and CT imaging findings, sub-pleural grid-like or honeycomb-like thickening of interlobular septum which is single or multiple, bronchial wall thickening, and thick strand-like and tortuous opacity. Multiple patchy consolidations, less commonly mild pleural effusion or enlargement of mediastinal lymph nodes, could be seen. Single or multiple solid nodules or consolidated nodules in the center of lobule, surrounded by ground-glass opacities are another less common picture [75].

The differential diagnosis of COVID-19 involves various respiratory tract viral infections [non
COVID-19 coronavirus, respiratory syncytial virus, para influenza, influenza and adenovirus], atypical bacterial infection such as mycoplasma, chlamydia and legionella. The differentiation of COVID-19 from such infections is sometimes not possible. So travel history becomes essential. However, as the epidemic spreads, the travel history will become irrelevant [76].

\section{TREATMENT}

No FDA-approved specific antiviral therapies are recommended for COVID-19 and there is no specific vaccine available until the date of writing this review [77]. Until now, the therapeutic strategies to deal with COVID-19 are only supportive. There are some anti-viral therapies created based on observational studies and case reports and no strong recommendation to hold up to date. These anti-viral therapies will be discussed in this review.

Indication for early antiviral treatment: Some studies have shown that the earliest possible start of antiviral therapy reduces serious complications of the disease (especially acute respiratory failure). The anti-viral treatments are highly indicated in patients with virologically ascertained diagnosis of infection by COVI-19 who had:

- Mild symptoms but with the presence of comorbidities or increased mortality risk;

- Clinical manifestations of moderate or severe disease.

REMDESIVIR (compassionate use only) [78]

* Investigational antiviral drug, which initially developed for treatment of Ebola. It has been shown to inhibit SARS-CoV-2 in vitro.

* Phase 3 trials are not published.

* Mechanism of action: nucleotide analogue, inhibiting RNA-dependent RNA polymerase.

* Dose: Pediatric: < $40 \mathrm{~kg}$ : $5 \mathrm{mg} / \mathrm{kg}$ on day 1 , followed by maintenance dose of $2.5 \mathrm{mg} / \mathrm{kg}$ q24h.Adult: loading dose: $200 \mathrm{mg}$ on day 1 then maintenance dose of $100 \mathrm{mg}$ OD for another 4 to 9 days according to clinical response, the dose should be intravenously infused over 30 to 120 minutes.

* Side effects- Elevated transaminases, reversible kidney injury, hypotension during infusion.

* Drug metabolism: it is a prodrug requiring CYP3A4 for activation thus there is potential 
for reduced conversion in the presence of CYP3A4 inhibitors like lopinavir/ritonavir.

\section{CHLOROQUINE/HYDROXYCHLOROQUI} NE

* Clinical studies have shown activity of chloroquine phosphate in vitro and in animal models as antiviral against the SARS virus [79].

* Mechanism of action: it increases the $\mathrm{pH}$ of the phagolysosome, which interrupts virus/cell fusion, as well as interferes with the glycosylation of cellular receptors of SARSCoV [79].

* Dose: [80]

> Hydroxychloroquine: Adult, 400mg PO Q12h x 1 day, 200mg PO Q12h x 4 days. Pediatric, $6.5 \mathrm{mg} / \mathrm{kg} / \mathrm{Dose}$, PO q12h $\mathrm{x} 1$ day, then $3.25 \mathrm{mg} / \mathrm{kg} /$ Dose, PO q12h x 4 days (up to adult maximum dose)(Half-life is 22.4 days).

$>$ Chloroquine: $500 \mathrm{mg}$ bid for 7 days for adult aged 18-65years with body weight over $50 \mathrm{Kg}$; 500mg bid for Days 1 \& 2and 500mg qd for Days 3-7 for adults with body weight below $50 \mathrm{Kg}$.

* Chloroquine/Hydroxychloroquine is generally safe drug for short term use, with few drugdrug interactions and inexpensive.

* Hydroxychloroquine may be used for chemoprophylaxis (800 $\mathrm{mg}$ divided into 2 doses for the first day then $400 \mathrm{mg}$ weekly or $200 \mathrm{mg}$ daily for frontline healthcare workers and $200 \mathrm{mg}$ every 5 days for others).

* Side effects: Nausea and diarrhea, QTc prolongation, Most toxicities are associated with long-term use, Retinopathy with prolonged use ( $>5$ years), not in the acute setting.

* G6PD testing only recommended for patients of Asian, African and Mediterranean descent.

* Safe in pregnancy.

* No dosing adjustment for hepatic or renal impairment or obesity.

\section{Monitoring for Hydroxychloroquine (HCQ) [81]:}

- The estimated half-life is 40 days

- Monitor for hemolytic anemia with CBC every 2 days. Post-marketing studies suggest the risk of hemolysis is very low. Hydroxychloroquine can be started in most patients while waiting G6PD testing.

- Avoids taking hydroxychloroquine with antacids. At least 4 hours apart between administrations of these drugs.
- $\mathrm{CrCl}<10$ and hemodialysis: reduce dose to $400 \mathrm{mg}$ po $\mathrm{x} 1$ day then 200mg po, OD.

- Risk of QT prolongation: should be used with caution if other QT prolonging agent such as azithromycin or fluoroquinolones or if electrolytic imbalances (Keep potassium > $4.0 \mathrm{mg} / \mathrm{dL}$ and Magnesium $>0.82 \mathrm{mmol} / \mathrm{L}$ ).

- Cardiac monitoring guidance [82]:

Given the growing evidence of myocarditis and arrhythmias with COVID, HCQ should be used with caution in this group of patients.

Obtain baseline ECG.

If on telemetry, check QTc and see if that corresponds to ECG QTc, if yes, use telemetry for further QTc monitoring. Otherwise use ECG for monitoring as noted below.

$>$ Discontinue all other QT prolonging agents.

$>$ Do not start Hydroxychloroquine if baseline QTc > $500 \mathrm{msec}$ (or QTc > $550 \mathrm{msec}$ in wide QRS patients) or discuss with cardiology if benefit vs risk is deemed high.

$>$ Be cautious if Baseline QTc > $470 \mathrm{msec}$ (or QTc $>520 \mathrm{msec}$ in wide QRS patients).

$>$ Check Telemetry QTc/ Acquire ECG, preferably $>2$ hours after the 2nd dose of 400 mg Hydroxychloroquine.

$>$ If QTc increases by less <50 msec; and if absolute QTc $<500 \mathrm{msec}$ ( $<550$ in wide QRS), use lower dose.

$>$ If QTc increases by $>50 \mathrm{msec}$; or if absolute QTc > $500 \mathrm{msec}$ (>550 in wide QRS), use lower dose and recheck ECG daily for 2 days.

Any evidence of Torsades on Telemetry, discontinue Hydroxychloroquine regardless of QT interval.

Note that wide QRS defined as QRS > 120 msec.

The efficacy of hydroxychloroquine or chloroquine, when used alone or with a macrolide, was recently questioned(needs more studies). Furthermore, the in-hospital outcomes for COVID-19 was even worse. Each of these drug regimens was associated with decreased inhospital survival and an increased frequency of ventricular arrhythmias when used for treatment of COVID-19 [83] (needs evidence).

\section{Lopinavir/Ritonavir [84]:}

* Reduces viral replication by $50 \%$ in MERS COV in vitro.

* Definite efficacy not proven in treatment of COVID-19. 
* Mechanism of action: it is a known antiretroviral second generation which inhibits the viral protease of HIV.

* It is tried in combination with Interferon alpha and/or Ribavirin in treatment of MERSCOV.

* Potent CYP3A4 inhibitor - monitor for drug interactions.

* Side effects: Elevated transaminases, hyperbilrubinemia, Nausea, Vomiting, Significant drug interactions (e.g., azoles, anticoagulants, anti-epileptics).

* Liquid and oral formulations are available.

* Safe in pregnancy.

* Dose:

> Adult: one tablet contains (Lopinavir200mg/ritonavir 50mg), give 2 tablets PO Q12h for 6-10 days.

$>$ Pediatric: Pediatric (based on lopinavir):

- Oral solution: < $15 \mathrm{~kg}: 12 \mathrm{mg} / \mathrm{kg} /$ dose $\mathrm{q} 12 \mathrm{~h}$.

15-40kg: $10 \mathrm{mg} / \mathrm{kg} /$ dose q $12 \mathrm{~h}$.

$>40 \mathrm{~kg}$ : $400 \mathrm{mg}$ q $12 \mathrm{~h}$.

- Oral tablet: $\geq 15-25 \mathrm{~kg}$ : $200 \mathrm{mg} \mathrm{q} 12 \mathrm{~h}$. $\geq 25-35 \mathrm{~kg}: 300 \mathrm{mg}$ q $12 \mathrm{~h}$.

$>35 \mathrm{~kg}$ : $400 \mathrm{mg} \mathrm{q} 12 \mathrm{~h}$

Favipiravir [85]:

* It is a novel antiviral drug

* Mechanism of action: Favipiravir specifically targets the RNA Dependent RNA Polymerase (RdRP) but does not interfere with host RNA and DNA polymerases, meaning it is a selective inhibitor of viral RNA synthesis.

* Favipiravir is active against a broad range of RNA viruses.

* Used by Japan and China to treat uncomplicated influenza.

* At this moment, its efficacy and safety have not been established.

* Dose: limited data available on the optimal duration \& dose, $1800 \mathrm{mg}$ BD for one day, then $800 \mathrm{mg}$ BD for 7 to 14 days, no need dose adjustment in renal impairment.

\section{Ribavirin [86]:}

* It was used in clinical practice during the SARS epidemic and the MERS-CoV epidemic. No study results yet in SARS $\mathrm{CoV} 2$.

* Mechanism of action: Inhibitor of RNA polymerization.

* Dose: loading dose: 2,000 mg po, followed by $10 \mathrm{mg} / \mathrm{kg}$ q $8 \mathrm{~h}$, po for 10 days.

* High risk of toxicity: hemolytic anemia or cytopenia. Therefore, if ribavirin is to be used, the patient should be closely monitored for hemolytic anemia and other major adverse effects

* Renal dose adjustment is necessary.

\section{TOCILIZUMAB}

* Tocilizumab is FDA-approved for the treatment of several disorders, including cytokine release syndrome [87].

* The interest in using tocilizumab to treat persons with COVID-19 is based on the observations that some persons with COVID19 develop a massive inflammatory response that can result in acute respiratory distress syndrome (ARDS), multi-organ failure, and potentially death [33]. This massive systemic inflammatory response has been characterized as a cytokine storm and very high levels of IL-6, thereby suggesting IL-6 may play a central role in the acute clinical decompensation [88].

* Tocilizumab is a humanized monoclonal antibody that binds to interleukin (IL)-6 receptors, thereby could potentially diminish this massive systemic inflammatory response [89].

* To this end, we recommend Tocilizumab be restricted to a much selected group of patients.

\section{* Inclusion Criteria[90]:}

Criteria for initiation of Tocilizumab in patients who are at high-risk for developing cytokine storm, includes ( 2 or more of the following):

1-Positive COVID-19.

2-All of the following respiratory findings:

- Abnormal chest imaging consistent with COVID-19.

- Rapidly deteriorating gas exchange/respiratory status over $24-48$ hours and requiring more than 4-6 L/min $\mathrm{O}_{2}$

- Absence of systemic fungal or bacterial coinfection.

- Mechanical ventilation for $\leq 48$ hours.

- Does not have a poor prognosis where they are unlikely to survive $>48$ hours.

- High clinical suspicion for cytokine release syndrome supported by:

Serum IL- $6 \geq 3 x$ upper normal limit.

Ferritin >300 ug/L (or surrogate) with doubling within 24 hours.

CRP > $100 \mathrm{mg} / \mathrm{L}$ with doubling within 24 hours 
Elevated D-dimer (>1 mg/L).

$>$ Ferritin $>600 \mathrm{ug} / \mathrm{L}$ at presentation and $\mathrm{LDH}$ $>250$.

* Exclusion Criteria[90]:

- Active Tuberculosis.

- Active Hepatitis B and Hepatitis C.

- Sepsis by other pathogens.

- Transaminases 10 times above reference values.

- Neutropenia (<1000 cell/mm3).

- Thrombocytopenia $(<50,000 / \mathrm{mm} 3)$.

- Patients on concomitant immunesuppressants, such as methotrexate or corticosteroids.

* Adverse effects: increased risk of reactivation of other Respiratory infections, elevation of liver enzymes, anemia and neutropenia.

* Dose: 4-8 mg/kg (usual dose: $600 \mathrm{mg} /$ dose; max: $800 \mathrm{mg} / \mathrm{dose}$ ) by IV infusion, maximum 2 doses 12 hours apart.

* Other IL-6 inhibitors: Sarilumab and Siltuximab (evaluated in clinical trials).

\section{CONVALESCENT PLASMA (CP) $[91,92]$}

* The use of convalescent plasma was recommended as an empirical treatment during outbreaks of Ebola virus in 2014.

* It was also used for treatment of MERS-COV.

* Mechanism of action: CP is a classic adaptive immunotherapy. When given to a susceptible person, this antibody will circulate in the blood, reach tissues, and provide protection against infection. Depending on the antibody amount and composition, the protection conferred by the transferred immunoglobulin can last from weeks to months. The principle of passive immunity builds on the premise that antibodies from CP may contribute to the clearance of the virus and also the improvement of symptoms. In addition to viral neutralizing antibodies, acceleration of infected cell clearance by antibodies.

* Dose: One unit of ABO compatible COVID19 convalescent plasma will be administered. The duration of infusion will usually take 1 to 2 hours (rate of 100 to $250 \mathrm{~mL} / \mathrm{hr}$ ).

* It is strongly recommended that convalescent plasma immediately transfused to the recipients on the same day it was obtained. It is also recommended that convalescent plasma administered at the early stage of disease.

* Very few studies published on the role of convalescent plasma containing neutralizing antibodies in SARS-Cov2, Two recently published studies have shown promising results especially in critically ill patients.

* Convalescent plasma with neutralizing antibodies have shown to improve clinical status, SOFA score, PAo2/FiO2 ratio and reduced viral load significantly.

Anticoagulation [93]: All patients should receive standard prophylactic anticoagulation with Low molecular weight heparin (LMWH) (enoxaparin $40 \mathrm{mg} \mathrm{SC}$ per day if D- dimer less than 1000 and $1 \mathrm{mg} / \mathrm{kg} / \mathrm{BID}$ if D-dimer more than 1000) in the absence of any contraindications (Contraindications include platelet count less than 25,000 or active bleeding); monitoring is advised in severe renal impairment; abnormal PT or APTT is not a contraindication.

* If LMWH contraindicated due to renal failure (Creatinine Clearance $<30 \mathrm{~mL} / \mathrm{min}$ ), Unfractionated Heparin 5000 units SC q12 (UFH) can be used as an alternative.

* Fondaparinux is preferred in those with heparin-induced thrombocytopenia.

* Direct acting anticoagulants(not used in $\mathrm{CrCl}<30$,Child-Pugh B,C) as rivaroxaban(10 $\mathrm{mg}$ per day for prophylaxis if $\mathrm{D}$ - dimer less than 1000 and $15 \mathrm{mg}$ twice per day if Ddimer more than 1000)and apixaban may be used with caution as antivirals and azithromycin may increase their plasma level.

* The duration of prophylactic anticoagulants is 31-39 days for post-discharge moderate and severe cases while the therapeutic anticoagulants are continued for 3 weeks .

\section{AZITHROMYCIN [83,94]:}

* No activity for SARS-CoV-2. Single study of combination therapy with hydroxychloroquine does not convincingly suggest added benefit to azithromycin combination therapy, given the study was recently retracted and concern for antibiotic overuse.

Corticosteroids [95,96]:There is significant interest and controversy surrounding the role of corticosteroids for the management of severe covid-19 pneumonia.

* The potential benefit of these agents to blunt the inflammatory cascade seen in severe disease needs to be carefully weighed against 
the concerns for secondary infections, adverse events, and other complications of corticosteroid therapy.

* The data for corticosteroids are inconsistent, confusing, and inconclusive. Clinicians need to carefully weigh the risks and benefits of corticosteroids on the individual patient level. This need for a risk benefit assessment in individual patients and careful consideration of dose is exemplified in the COVID-19. Diagnosis and Treatment Guide from the National Health Commission of the People's Republic of China where the authors state "Based on respiratory distress and chest imaging, may consider glucocorticoid that is equivalent to methylprednisolone 1-2 $\mathrm{mg} / \mathrm{kg} /$ day for 3-5 days or less.

* Large-dose glucocorticoid suppresses immune system and could delay clearance of SARS-CoV-2." A recent consensus statement from the Chinese Thoracic Society recommends a lower dose, $\leq 0.5-1 \mathrm{mg} / \mathrm{kg} / \mathrm{day}$ methylprednisolone for $\leq 7$ days in select patients, after careful consideration of risks and benefits. Dexamethasone $6 \mathrm{mg} /$ day/10 days oral or I.V. are recommended for patients on mechanical ventilation or not but require supplemental oxygen[166].

* WHO and CDC do not recommend the routine use of steroids in patients with COVID-19 pneumonia at this time. Use of steroids in patients with severe disease (requiring oxygen support or mechanical ventilation) could be considered as part of the supportive care regimen for patients with ARDS on a case-by-case basis.

\section{ASCORBIC ACID [97]:}

* Ascorbic acid has numerous proven biological properties (anti-inflammatory, antioxidant, immune enhancing, antiviral) that are likely to be of benefit in patients with COVID-19 disease.

* Furthermore, it is important to stress that ascorbic acid has proven synergistic effects when combined with corticosteroids. Therefore, steroids are recommended in patients with COVID-19 and respiratory failure. The benefit of ascorbic acid (without corticosteroids) in patients with severe respiratory failure appears to be limited.

* While the optimal dose of ascorbic acid is unknown, we suggest $3 \mathrm{~g}$ IV q 6 hourly. It should be noted that in the presence of free iron (released from ferritin) ascorbic acid may potentially have pro-oxidant effects. Therefore, the trends in CRP and ferritin need to be closely monitored; in those patients who ferritin and CRP are increasing, reducing the dose to $1.5 \mathrm{~g}$ q 6 hourly should be considered.

* However, no high-quality evidence supports the use of ascorbic acid in viral pneumonia.

\section{Vitamin D [98]:}

- Vitamin D has important immune-enhancing effects. Much of the population, especially the elderly have sub-optimal vitamin D levels, particularly during the winter months. Low vitamin $\mathrm{D}$ levels have been shown to increase the risk of developing viral upper respiratory tract infections. Therefore, prophylactic vitamin D should be considered especially in the elderly.

\section{ZINC [99]:}

* Zinc $(\mathrm{Zn}++)$ inhibits viral RNA dependent RNA polymerase (replicase). Chloroquine and hydroxychloroquine are potent $\mathrm{Zn}$ ionophores that increase intracellular $\mathrm{Zn}$ concentrations.

* This provides an interesting basis for further studies into the use of zinc- ionophores as antiviral compounds, although systemic effects have to be considered

* It has only been observed in-vitro. Oral supplementation of $\mathrm{Zn}$ has not been investigated. $\mathrm{Zn}$ needs special ionophore to be transported into a cell, to inhibit RNA replication.

\section{Melatonin [100]:}

* Very recent data suggests that in addition to being a potent anti-oxidant, melatonin may have direct antiviral effects against COVID19. In healthy people, melatonin levels plummet after the age of 40 years. This may partly explain the increased risk of death in patients with COVID-19 who are over the age of 40. Melatonin may therefore have a role in both the prevention and treatment of COVID19.

\section{ANTI BACTERIAL THERAPY [101]}

* Bacterial pneumonia can emerge during the hospital stay (especially ventilator-associated pneumonia in patients who are intubated).

* They can be treated similarly to other hospital-acquired pneumonias or ventilatorassociated pneumonias. Data has shown secondary bacterial infections are late manifestation of the COVID-19 disease process. 
Broad spectrum antibiotics can be started to treat secondary bacterial pneumonia according to the local institutional guidelines.

* Routine use of empiric antibiotics is strongly not recommended in COVID-19.

* Antibiotics can be started if high suspicion for secondary bacterial infection (ie PCT $\geq 0.5$ ).

* Doxycycline (may be used for prophylaxis), linezolid and azithromycin have antiviral effect.

\section{Angiotensin-receptor blockers and Angiotensin converting enzyme inhibitors [102]:}

Whether patients with COVID-19 and hypertension who are taking an ACE inhibitor or angiotensin-receptor blocker should switch to another antihypertensive drug remains controversial and there is no evidence support discontinuation of ACEi/ARB therapy to decrease risk for more severe COVID-19 at this time. There is some growing evidence showing that ARBS and ACE inhibitors improve clinical outcomes in COVID-19 patients [102].

Recombinant ACE-2 enzyme, as an inhaler may be useful to reach the receptors in the lung locally, and antiviral drugs could be interesting combination. However, the exact efficacy of this combination in COVID-19 treatment is not proved.

\section{Ibuprofen/NSAIDs [103]:}

* Do not discontinue these therapies for COVID-19 disease. Paracetamol is the preferred fever reducer for use in COVID-19. Although there has been theoretical concern raised for these agents worsening outcomes, no data currently exist to support this.

* FDA is not aware of scientific evidence connecting the use of NSAIDs, like ibuprofen, with worsening COVID-19 symptoms.

\section{OTHER AGENTS under investigation}

* Darunavir/Cobicistat

* Umifenovir(Arbidol)- 200 mg TDS

* Ivermectin : Patrì and Fabbrocini hypothesized that "hydroxychloroquine (HCQ) and ivermectin could act in a consequential and synergistic manner. HCQ would behave as a first-level barrier by inhibiting the entry of the virus into the host cell, while ivermectin could reduce viral replication if the virus did get in, strengthening HCQ antiviral
effects"[163].Ivermectin is metabolized in liver and excreted in stool over 12 days. The half-life is 18 hours[165]. The suggested dose is 300 microgram per $\mathrm{kg} /$ day for 3 successive days for treatment and 300 micrograms per $\mathrm{kg}$ /day to be repeated after 48 hours(2 doses only) for prophylaxis of contact of positive case .It also may be used for one dose(300 micrograms per $\mathrm{kg}$ ) every week(most common side effects are gastritis and sleepiness) with weekly HCQ as a prophylaxis for the frontline health care workers(needs human clinical trials).

* Nitazoxanide(with azithromycin).

* Traditional medicines in different countries as Traditional Chinese Medicine (TCM) treatment(Yin Qiao San, Yu Ping Feng San, Sang Ju Yin and Yu Ping Feng San ,Lian Hua Qing Wen Capsule, Shuang Huang Lian and Ma Xin Gan Shi Tang), Madagascar covid 19 organic syrup made from Artemisia апnиa (sweet wormwood) and herbs(in some African countries) and Honey and Nigella Sativa in Pakistan Trial Against COVID-19.

* Human Mesenchymal Stem Cells: Under clinical trials for treatment of critically ill covid 19 patients.

\section{The need for ICU management}

Most patients with COVID-19 only show mild illness $(81 \%)$; however, $14 \%$ approximately of the patients requires hospitalization and oxygen support. 5\% of the patients requires monitoring in the Intensive Care Units [104,105].

Patients with mild illness do not need to be hospitalised, but isolation of them is necessary to contain spread of the virus [106-107]. Provide them with symptomatic treatments including antipyretics for fever associated with the infection, and counsel them to ask for medical help if any complications take place[106-107]. Provide patients with supplemental oxygen therapy immediately that are with SARI and respiratory distress, shock or hypoxemia and target $\mathrm{SpO} 2>94 \%[\mathbf{1 0 6}, \mathbf{1 0 7}]$.

Adults with critical signs (obstructed or absent breathing, severe respiratory distress, central cyanosis, shock, coma, or convulsions) should receive airway management and oxygen therapy during resuscitation to target $\mathrm{SpO} 2 \geq 94 \%$. 
Initiate oxygen therapy at $5 \mathrm{~L} / \mathrm{min}$ and titrate flow rates to reach target $\mathrm{SpO} 2 \geq 93 \%$ during resuscitation; or use face mask with reservoir bag (at $10-15 \mathrm{~L} / \mathrm{min}$ ) if patient in critical condition. Once patient is stable, the target is $>90 \% \mathrm{SpO} 2$ in non-pregnant adults[94] and $\geq 92-95 \%$ in pregnant patients [106,107].

Patients with hypoxemic respiratory failure should receive non-invasive ventilation (NIV). Patients with hypoxemic respiratory failure should receive high-flow nasal oxygen (HFNO). Patients treated with either HFNO or NIV should be closely monitored for clinical progression [106,107].

An RCT of ECMO for adult patients with ARDS was stopped early and found no statistically significant difference in the primary outcome of 60-day mortality between ECMO and standard medical management (including prone positioning and neuromuscular blockade) [108]. However, ECMO was associated with a reduced risk of the composite outcome of mortality and crossover to ECMO [108] and a post hoc Bayesian analysis of this RCT showed that ECMO is very likely to reduce mortality across a range of prior assumptions [109]. In patients with MERS, ECMO vs conventional treatment was associated with reduced mortality in a cohort study [110]. ECMO should be offered only in expert centers with a sufficient case volume to maintain expertise and that can apply the IPC measures required for adult and pediatric COVID-19 patients [111-112].

Acute hypoxemic respiratory insufficiency or failure requiring oxygen and ventilation therapies is a common complication of COVID- 19 . Sometimes the disease progress in spite of mechanical ventilation (Figure 4) $[\mathbf{4 5 , 1 0 4 ]}$. In a recent report $14 \%$ of patients reported to developed dyspnea, desaturation with peripheral oxygen saturation $\left(\mathrm{SpO}_{2}\right) \leq 93 \%$, tachypnea with a respiratory rate $\geq 30$ per minute, poor oxygenation with a ratio of partial pressure of arterial oxygen $\left(\mathrm{PaO}_{2}\right)$ to fraction of inspired oxygen $\left(\mathrm{FIO}_{2}\right)<300 \mathrm{mmHg}$, or lung infiltrates $>$ $50 \%$ within 48 hours [60].

\section{Suggested therapeutic protocols for COVID- 19 patients [77,113]:}

No proven therapeutic protocols for treatments of COVID-19. The following therapeutic protocols are suggested on the basis of information available till date on different investigational treatment approaches.

\begin{tabular}{|c|c|c|}
\hline Severity of illness & Clinical presentation & Plan \\
\hline $\begin{array}{l}\text { Mild Uncomplicated Infection illness } \\
\text { Symptomatic patient with leucopenia } \\
\text { or lymphopenia with no radiological } \\
\text { signs of pneumonia. }\end{array}$ & \begin{tabular}{|l|}
-Age less than60y. \\
-Fever less than 38. \\
-SaO2 $>92$. \\
-Heart Rate $<110$. \\
-Respiratory rate $<25$. \\
-Neutrophils/lymphocytes ratio \\
$<3.1$. \\
-Controlled comorbidities. \\
-Non Pregnant. \\
- No active malignancy. \\
-Not on chemotherapy. \\
-BMI <40. \\
-Not on immunosuppressive \\
drugs.
\end{tabular} & $\begin{array}{l}\text { Patient should be isolated at home. } \\
\text { Droplet \& contact precautions } \\
\text { Clinical observation(if any deterioration occurs ,back to } \\
\text { hospital). } \\
\text { No specific antimicrobial advised } \\
\text { Supportive treatment:: } \\
\text { Vitamin C 500mg BID. } \\
\text { Lactoferrin.; twice per day. } \\
\text { Zinc } 50 \mathrm{mg} \text { per day. } \\
\text { Vitamin D3 } 1000-4000 \mathrm{u} / \mathrm{day} \text {. } \\
\text { Acetylcystiene } 200 \mathrm{mg} \text { tds. } \\
\text { Symptomatic drugs e.g antipyretic(paracetamol is preferred). } \\
\quad \text { Hydroxychloroquine, } 400 \mathrm{mg} \text { PO Q12h x } 1 \text { day, } 200 \mathrm{mg} \text { PO } \\
\text { Q12h x } 6 \text { days or Ivermectin } 300 \text { microgram per kg /day for } 3 \\
\text { successive days or Favipiravir . }\end{array}$ \\
\hline $\begin{array}{l}\text { Mild Uncomplicated Infection illness } \\
\text { Symptomatic patient with leucopenia } \\
\text { or lymphopenia with no radiological } \\
\text { signs of pneumonia. }\end{array}$ & \begin{tabular}{|l|}
-Age $>60 y$. \\
-Fever more than 38. \\
- SaO2 $<92$. \\
- Heart Rate $>110$. \\
-Respiratory rate $>25$. \\
-Neutrophils/lymphocytes ratio \\
$>3.1$. \\
-Uncontrolled comorbidities. \\
-Pregnant. \\
-Active malignancy. \\
-On chemotherapy. \\
-BMI $>40$ (morbid obesity). \\
-On immunosuppressive drugs. \\
\end{tabular} & $\begin{array}{l}\text { Should be isolated at COVID centers. } \\
\text { Supportive \&Symptomatic treatment as above. } \\
\text { Consider starting hydroxychloroquine, } 400 \mathrm{mg} \text { PO Q12h x } 1 \\
\text { day, 200mg PO Q12h x } 6 \text { days or Ivermectin } 300 \text { microgram } \\
\text { per kg /day for } 3 \text { successive days or Favipiravir . } \\
\text { Observe closely. } \\
\text { Avoid Nebulization and if inhaler medications are needed, use } \\
\text { metered-dose inhaler(MDI )and spacer device. }\end{array}$ \\
\hline Moderate Illness & $\begin{array}{l}\text {-Pneumonia on radiology } \\
\text { associated with symptoms. } \\
-<50 \% \text { lung involvement on } \\
\text { imaging. }\end{array}$ & $\begin{array}{l}\text { Supportive \&Symptomatic treatment and isolation as above. } \\
\text { Enoxaparin } 40-60 \mathrm{mg} \text { day (if not contraindicated; dose adjust } \\
\text { with } \mathrm{CrCl}<30 \mathrm{ml} / \mathrm{min} \text { )or } 1 \mathrm{mg} / \mathrm{kg} / \mathrm{BID} \text { if D-dimer }>1000 \text {. } \\
\text { Consider starting hydroxychloroquine, } 400 \mathrm{mg} \text { PO Q12h x } 1\end{array}$ \\
\hline
\end{tabular}

Saeed et al., Afro-Egypt J Infect Endem Dis 2020;10(2):65-92

https://aeji.journals.ekb.eg/

http://mis.zu.edu.eg/ajied/home.aspx 


\begin{tabular}{|c|c|c|}
\hline & & $\begin{array}{l}\text { day, 200mg PO Q12h x } 9 \text { days plus Ivermectin } 300 \\
\text { microgramper kg /day for } 3 \text { successive days or } \\
\text { Lopinavir/Ritonavir( } 2 \text { tab/12h) with ripavirin (400mg/12h for } \\
14 \mathrm{~d} \text {, not if symptoms started more than } 7 \text { day) or Favipiravir } \\
\text { Corticosteroids if patient is dyspneic or chest CT deterioration. } \\
\text { N/C O2, } 2 \mathrm{~L} / \mathrm{min} \text { if needed (max } 4 \mathrm{~L} / \mathrm{min} \text {; consider early } \\
\text { transfer to ICU for escalation of care). } \\
\text { Avoid Nebulization and if inhaler medications are needed, use } \\
\text { MDI and spacer device. } \\
\text { Avoid non-invasive ventilation. } \\
\text { Start empirical antibiotics(azithromycin, doxycycline or } \\
\text { levofloxacin ) as per local institutional protocol for treatment of } \\
\text { community acquired pneumonia(add meropenem or cefepime }+ \\
\text { linezolide if needed). }\end{array}$ \\
\hline Severe Illness & $\begin{array}{l}\text {-Respiratory rate }>30 / \mathrm{min} \text {. } \\
-\mathrm{SPo} 2<92 \% \text { on room air. } \\
->50 \% \text { lung involvement on } \\
\text { imaging.. } \\
-\mathrm{PaO} 2 / \mathrm{FiO} 2<300 \\
-\mathrm{High} \text { risk factors for severe } \\
\text { illness. }\end{array}$ & $\begin{array}{l}\text { Initiate/continue the treatment plan for moderate illness (if not } \\
\text { given before) } \\
\text { High flow O2 support (HFNC/NIV) taking adequate } \\
\text { precautions to reduce aerosolization } \\
\text { Awake proning can be tried as a rescue measure } \\
\text { Consider starting hydroxychloroquine, } 400 \mathrm{mg} \text { PO Q12h x } 1 \\
\text { day, 200mg PO Q12h x } 9 \text { days plus Ivermectin } 300 \text { microgram } \\
\text { per kg /day for } 3 \text { successive days OR plus Lopinavir/Ritonavir } \\
\text { plus azithromycin or doxycycline. OR } \\
\text { Lopinavir/Ritonavir+ribavirin+interferon +azithromycin or } \\
\text { Doxycycline or Favipiravir or Remdesivir. }\end{array}$ \\
\hline Critical Illness & $\begin{array}{l}\text {-Respiratory failure, Shock, } \\
\text { Multi organ dysfunction. } \\
\text { - } \mathrm{PaO} 2 / \mathrm{FiO} 2<200 \text {. }\end{array}$ & 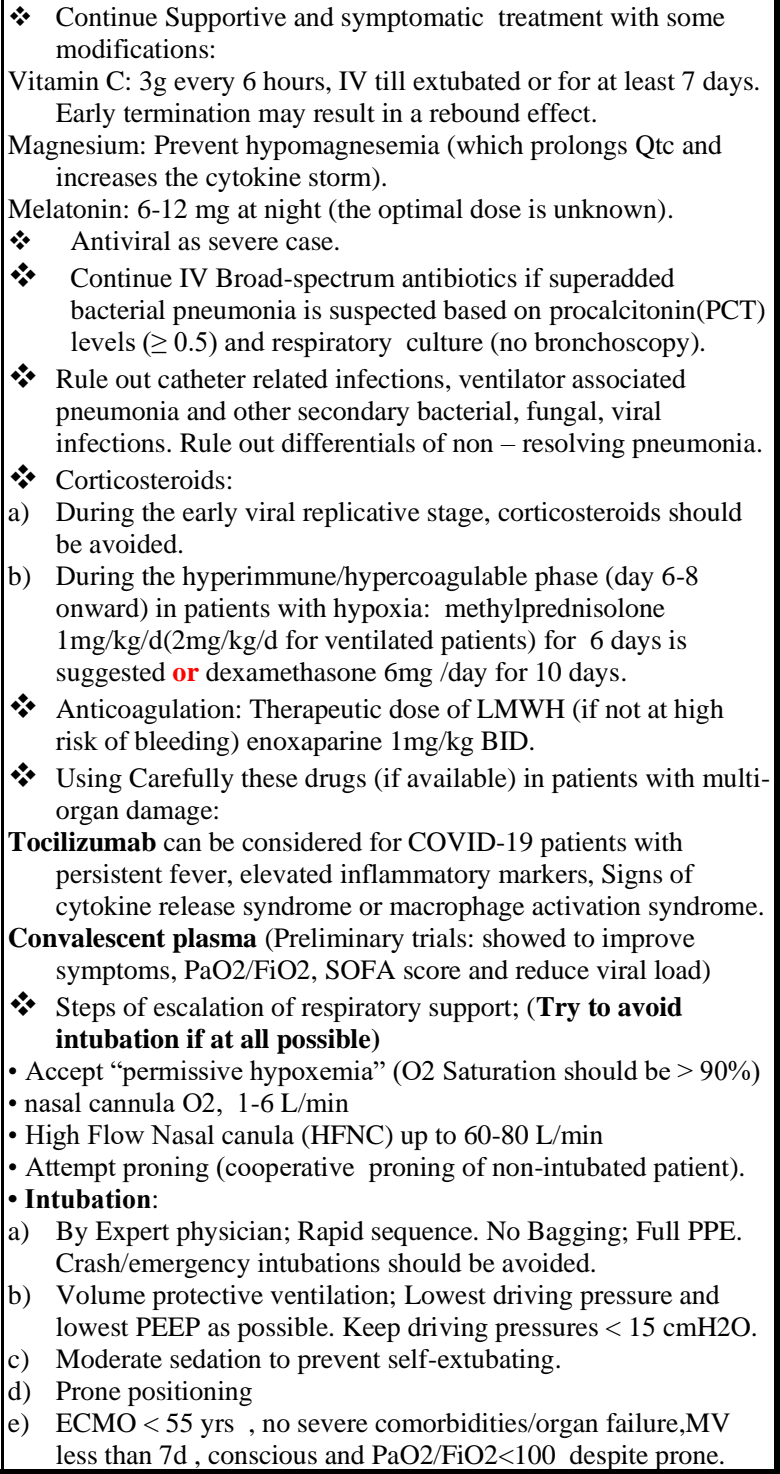 \\
\hline
\end{tabular}

Discharge Guidance: The criteria of discharge from isolation are described in Table 3.

Saeed et al., Afro-Egypt J Infect Endem Dis 2020;10(2):65-92

https://aeji.journals.ekb.eg/

http://mis.zu.edu.eg/ajied/home.aspx 
Recently; discharge are divided into:

1. Time based discharge: After 10 days of positive test (for asymptomatic cases).

2. Symptom based discharge: After 10 days of start of symptoms with the last 3 days without symptoms(no fever or respiratory symptoms) (mostly for mild symptomatic cases), $\mathrm{SaO} 2>92 \%$ on room air with stable chest imaging(for moderate cases).

3. Test based discharge: For hospitalized patients with risk factors and morbidity (table 3).

Table (3): Comparison of current guidelines on de-isolation of COVID-19 cases

\begin{tabular}{|c|c|c|}
\hline & $\begin{array}{l}\text { Asymptomatic infected persons, } \\
\text { isolated at home or institutional }\end{array}$ & hospitalized Symptomatic cases \\
\hline $\begin{array}{|lr|}\text { CDC USA } & \\
\text { Interim guidance for } \\
\text { discontinuation } \\
\text { transmission-based } \\
\text { precautions of } \\
\text { disposition of hospitalized } \\
\text { patients with COVID-19 } \\
{[114] .}\end{array}$ & $\begin{array}{l}\text { At least negative } 2 \text { consecutive rRT- } \\
\text { PCR test of nasopharyngeal and throat } \\
\text { swabs collected } \geq 24 \text { hours apart from } \\
\text { a patient with COVID-19 (a total of } \\
\text { four negative samples) } \\
\text { Note: decision to be taken on a case- } \\
\text { by-case basis in consultation with } \\
\text { clinicians and public health officials }\end{array}$ & $\begin{array}{l}\text { Negative rRT-PCR results from at least } 2 \text { consecutive } \\
\text { samples of nasopharyngeal and throat swabs collected } \\
\geq 24 \text { hours apart from a patient with COVID-19 (a total } \\
\text { of four negative samples). } \\
\text { AND improvement in illness signs and symptoms, } \\
\text { resolution of fever without use of antipyretic } \\
\text { medication. } \\
\text { Note: decision to be taken on a case-by-case basis in } \\
\text { consultation with clinicians and public health officials. }\end{array}$ \\
\hline $\begin{array}{|lll|}\text { Italy } & & \\
\text { Ministero } & \text { della } & \text { salute, } \\
\text { Consiglio } & \text { Superiore } & \text { di } \\
\text { Sanità [115]. } & \end{array}$ & $\begin{array}{l}\text { Negative SARS-CoV-2 PCR test from } \\
\text { respiratory samples at } 14 \text { days after } \\
\text { the initial positive test (end of the } \\
\text { quarantine period). }\end{array}$ & $\begin{array}{l}\text { A COVID-19 patient can be considered cured after the } \\
\text { resolution of symptoms and } 2 \text { negative tests for SARS- } \\
\text { CoV-2 from respiratory samples at least } 24 \text {-hour intervals. } \\
\text { For patients who clinically recover earlier than } 7 \text { days } \\
\text { after onset, an interval of } 7 \text { days between the first and the } \\
\text { final test is recommended. } \\
\text { Note: Virus clearance is defined as viral RNA } \\
\text { disappearance from bodily fluids of symptomatic and } \\
\text { asymptomatic persons, accompanied by appearance of } \\
\text { specific IgG. }\end{array}$ \\
\hline ECDC [116]. & & $\begin{array}{l}\text { COVID- } 19 \text { patients may be discharged from hospital and } \\
\text { moved to home care based on: } \\
\text { clinical criteria (e.g. no fever for > } 3 \text { days, improved } \\
\text { respiratory symptoms, pulmonary imaging showing } \\
\text { obvious absorption of inflammation, no hospital care } \\
\text { needed for other pathology, clinician assessment). } \\
\text { Laboratory evidence of SARS-CoV-2 clearance in } \\
\text { respiratory samples; } 2 \text { to } 4 \text { negative rRT-PCR tests for } \\
\text { respiratory tract samples (nasopharynx and throat swabs } \\
\text { with sampling interval } \geq 24 \text { hours). Testing at a minimum } \\
\text { of } 7 \text { days after the first positive RT-PCR test is } \\
\text { recommended for patients that clinically improve earlier. } \\
\text { Serology: appearance of specific IgG when an appropriate } \\
\text { serological test is available. }\end{array}$ \\
\hline $\begin{array}{l}\text { China CDC } \\
\text { Diagnosis and treatment } \\
\text { protocol for COVID-19 } \\
\text { patients (trial version 7, } \\
\text { revised) [117]. }\end{array}$ & & $\begin{array}{l}\text { Patients meeting the following criteria can be discharged: } \\
\text { - Improved respiratory symptoms. } \\
\text { - Afebrile for }>3 \text { days. } \\
\text { inflammation, and } \\
\text { - Negative PCR test for SARS-CoV-2 twice } \\
\text { consecutively from respiratory samples (sampling } \\
\text { interval } \geq 24 \text { hours). } \\
\text { After discharge, covid- } 19 \text { patients are recommended to } \\
\text { continue } 14 \text { days of isolation management and health } \\
\text { monitoring, wear a mask, reduce close contact with family } \\
\text { members, live in a single room with good ventilation, } \\
\text { keep hands clean and avoid outdoor activities, eat } \\
\text { separately. } \\
\text { It is recommended that discharged patients should have } \\
\text { follow-up visits after } 2 \text { and } 4 \text { weeks. }\end{array}$ \\
\hline $\begin{array}{l}\text { National Centre for } \\
\text { Infectious } \quad \text { Diseases } \\
\text { (NCID) Singapore } \\
\text { De-isolation of COVID-19 } \\
\text { suspect cases [118]. }\end{array}$ & & $\begin{array}{l}\text { Discharge patient with advisory and clinic follow-up if } \\
\text { indicated and with daily wellness calls until day } 14 \text { after } \\
\text { last possible exposure, under the following conditions: } \\
\text { - Afebrile } \geq 24 \text { hours, } \\
\text { - } 2 \text { respiratory samples tested negative for SARS-CoV-2 } \\
\text { by PCR in } \geq 24 \text { hours, }\end{array}$ \\
\hline
\end{tabular}




\begin{tabular}{|l|l|l|}
\hline & $\begin{array}{l}\bullet \text { Day of illness from onset } \geq 6 \text { days } \\
\text { OR } \\
\bullet \text { Alternative etiology found (e.g. bacteremia, influenza) } \\
\text { OR } \\
\text { - Does not require in-patient care for other reasons. } \\
\bullet \text { Not a close contact of a COVID-19 case. }\end{array}$ \\
\hline
\end{tabular}

\section{PROTECTION}

A vaccine against COVID 19 is not expected to become available soon, so the main strategy of managing this pandemic is trying to decrease its spread, through various measures seeking to reduce the rate of new infections [119-120].

General:

The general precautions are the mainstay in facing this rapidly spreading pandemic. The lines of general protection include social distancing with home stay. Maintain a distance of at least 1.8 meter with other people. Hand hygiene practice, accurately with water and soap for at least 20 second if not actually available or applicable, can use hand sanitizer an alcoholbased with $60 \%$ concentration at least, and do not touch face with unwashed hands. Avoid crowdedness in different occasions to reduce the risk of transmission. In fact, many countries around the globe practiced different polices based mainly on avoiding personal crowdedness and some countries even applied widespread institutions shut down and curfew [121].

\section{Contact:}

Contact with persons suspected or confirmed to be infected with COVID-19 must wear at least minimum amount of PPE, different styles may be necessary to perform health related duties, which are disposable gloves, isolation coveralls and respirator mask as fit size N-95; facemasks are an acceptable alternative, and protection of the eye (disposable goggles or shield that must fully covers the face front and sides [122].

\section{Healthcare workers:}

Aerosols generating procedures on COVID-19 infected patients admitted in the ICU, it recommended to use approved fitted size respirator masks by healthcare workers, as compared to surgical masks, with other PPE in a negative-pressure room. Performing endotracheal intubation on infected patient is suggested by using, if available video guided laryngoscopy, over direct laryngoscopy. Usual care for nonventilated infected patients is by using surgical masks, as compared to respirator masks with other PPE [123]. Ensure trained personnel wearing suitable personal protective equipment (PPE), when dealing or transporting suspected cases. Globally, the incidence of health care workers catching the infection from handling the patients is increasing with high proportion of mortality, that is why an algorithm for dealing with health care workers is proposed (Figure 5).

\section{Environment disinfection procedures in hospitals}

- Surface disinfection is by whipping with chlorine-containing disinfectant at least $1000 \mathrm{mg} / \mathrm{L}$ concentration then wipe twice with ethanol $75 \%$ every four hour.

- Disinfection of equipment in the contaminated area is by wiping with disinfectant $2000 \mathrm{mg} / \mathrm{L}$ chlorine, while in the other areas are wiped with concentration $500-1000 \mathrm{mg} / \mathrm{L}$ chlorine or disposable disinfectant wipes alcohol-containing two times at a day.

- Disinfection of air is by shutting off the whole air conditioners especially the central to guard against spread of air contamination. Ventilation by door opening, more than 30 minutes, every 4 hours and inner shielding door closure when disinfection of air suspected, spraying air with $1000 \mathrm{mg} / \mathrm{L}$ chlorine disinfectant two times per day. Air disinfection is conducted for half hour before other patient examination.

- Disinfection of the ground is done by wiping it with chlorine disinfectant 1000 $\mathrm{mg} / \mathrm{L}$ concentration, every four hours.

- Disinfection should be done when visible contamination occur, absorbent disposable materials should be used to remove the pollutants firstly, then soak it with 2000 $\mathrm{mg} / \mathrm{L}$ chlorine disinfectant for at least half hour before whipping it [124].

\section{CARDOIVASCULAR AFFECTION WITH COVID 19}

\section{Cardiac injury:}

Recent studies stated that acute cardiac injury is an important manifestation of COVID- 19. Here, acute cardiac injury is defined as either increased cardiac troponin level $>99^{\text {th }}$ percentile alone or a composite of troponin elevation plus ECG or echocardiographic abnormalities $[45,125,126]$. 
Evidence of cardiac injury tend to occur in patients with comorbidities, including baseline hypertension, diabetes, coronary heart disease, and heart failure $[125,127]$ and associated with worse outcomes, including ICU admission and death $[45,25,127]$.

\section{Arrhythmia}

Arrhythmias have been reported in some patients with COVID-19 during their hospitalization with higher rates among ICU patients [45].

Arrhythmias including ventricular tachycardia or ventricular fibrillation were observed [127]. These findings are consistent with arrhythmias documented in influenza, which has been known to cause both AV node dysfunction and ventricular arrhythmias [128].

Heart failure, cardiogenic shock and myocarditis:

Heart failure and myocardial dysfunction have been described in COVID-19 [126], [129-132]. Some reports confirmed fulminant myocarditis by cardiac MRI [131]. In some case series [127], myocardial damage or heart failure contributed to $40 \%$ of deaths overall with $7 \%$ attributed only to circulatory failure without respiratory failure.

\section{Putative Mechanisms of Cardiovascular} Manifestations in SARS-CoV2 [127,133]:

Direct viral myocardial injury.

Microvascular injury.

Stress cardiomyopathy.

Acute coronary syndrome.

Myocardial injury secondary to oxygen supply and demand mismatch.

Systemic hyper-inflammatory response with resulting myocardial injury.

\section{LIVER AFFECTION WITH COVID}

19

COVID-19 also affects liver because ACE2 is expressed by liver and bile duct cells and COVID-19 uses ACE2 as its entry receptor causing damage to bile duct cells [134].

Pathology of affected liver with COVID-19 is moderate microvascular steatosis and mild portal and lobular activity [135]. Also asymptomatic COVID-19 patients who had less AST abnormality than symptomatic COVID-19 patients who had symptoms as fever and dry cough before their diagnosis.Liver damage is predominant in severe cases than mild cases of COVID-19 [60,136,137]. By lab investigation COVID-19 patients have an elevation of liver enzymes. In primary biliary cholangitis, COVID19 aggravates cholestasis also it causes an elevation in alkaline phosphatase and GGT. Patients with Hepatic cirrhosis and malignancy are more vulnerable to be infected with COVID19 due to their decreased immunity [60].

\section{COVID 19, GIT MANIFESTATIONS AND ENDOSCOPY}

Regarding COVID 19, respiratory symptoms are usually the presenting symptoms [138]. Less commonly, GIT symptoms were noticed, such as nausea, vomiting, abdominal discomfort, GIT upset and diarrhea. These symptoms usually appear prior to respiratory symptoms [139].

GIT tropism of SARS-CoV infection can be detected by intestinal biopsy and in the stools of discharged patients. This may explain the GIT symptoms of SARS-CoV and its potential recurrence [138].

Noted that the first case diagnosed in the United States reported 2 days history of nausea and vomiting on admission then developed loose stool during hospitalization [138]. The SRARSCOV 2 sequence could detected in the selfcollected saliva of most infected patients even not in naso-pharyngeal aspirate [139]. During hospitalization, viral load declining should be noticed in serial salivary specimens [139]. Many efforts should be made to be alert on the initial digestive symptoms of COVID-19 for early detection, diagnosis and isolation[138].

\section{COVID-19 and GIT Endoscopy}

SARS-CoV-2 coronavirus is a highly infectious disease. Patients with chronic diseases, autoimmune diseases and elderly are at high risk. Spread through contact, respiratory droplets and aerosols.

As endoscopy is a high aerosol generating procedure. Endoscopists must be careful and take precautions. Upper GIT endoscopy can generate aerosols during scope intubation, coughing and vomiting. Lower GIT endoscopy can generate aerosols through passing flatus during procedure [140-143].

\section{Recommendations [142,143]:}

Globally there is no consensus regarding performing GIT endoscopy in the era of COVID19. However, different endoscopic societies and different health care facilities released different regulatory recommendations for performing GIT endoscopy. The recommendations listed down are consistent with the global medical trend to differ non-emergency procedures to a later time 
after the pandemic had been controlled. These recommendations are mainly released to both protect health care workers, interfere with spread of the infection and ensure high quality procedures.

1- Postpone all elective endoscopic procedures. Emergency procedures should be performed under the strict precautions described below. Also, cases where the endoscopy will change their line of management i.e. time sensitive conditions e.g. patients with suspected malignancies should not be postponed.

2- Efficient history taking before endoscopy which includes (travel history, contact, occupational exposure and clustering)

3- Efficient clinical examination (Fever more than $38 \mathrm{C}^{\circ}$, Chest examination to detect chest diseases, abdominal examination to detect GIT symptoms and signs). Both will effectively triage patients presented for endoscopy.

4- Upper GIT endoscopies carry a higher risk of infectivity.

5- Lower GIT endoscopies could be infective.

6- Confirmed COVID-19 patients should undergo urgent procedures only (GIT bleeding, foreign body extraction, ERCP for cholangitis).

7- Personal Protective Equipments (PPE) during endoscopy:

- Respiratory mask ( FFP2/FFP3, CAPR, N95 )

- Waterproof full sleeve single use gown

- Gloves (some recommend double gloves with checking of its integrity before the procedures) [144].

- Protective eyewear

- Single use hairnet

- Single use show covers

\section{Operating theaters:}

a) The essential medical staff is preferred in the endoscopy room to decline the spread of SRAS-Cov-2 virus.

b) Pitfalls in using PPE are frequently encountered, so formal training on donning and doffing PPE and safe disposal is essential to prevent transmission within hospitals and especially the endoscopy unit.

c) Prior donning and post doffing PPE hand washing and sterilization.

d) If procedure needs endotracheal intubation, it is preferred to perform the procedure in a negative pressure room. Consequently, the endoscopy units needs to increase or develop their negative pressure room if not available.

e) During intubation, it is preferred that only the Anesthesia consultant and assisting nurse to be existing only in the theatre.

f) Between procedures, Room must be cleaned by veridical agents and disinfection.

g) When supplies of PPE are low, extended use is preferred over reuse due to lower risk of direct contamination resulting from frequent touching of the mask [145].

h) The endoscopy standard reprocessing instructions are efficient to destroy SARSCov-2 after revising the manufacturer's instructions.

i) Endoscopy disinfection should follow the standard disinfection guidelines. However, an extra 30 minutes disinfection after confirmed cases of COVI-19 may be advised.

j) It is advisable not to reuse disposable accessories.

k) However, we feel that follow-up of patients after endoscopic procedures is important during the COVID-19 pandemic, to help the endoscopy unit monitor the effectiveness of its policies and adjust them based on the rate of post-procedure infections.

\section{NEUROLOGICAL}

\section{MANIFESTATIONS OF COVID 19}

Neurological manifestations of COVID-19 have not been properly studied .Some patients, especially those with severe illness, have CNS manifestations [161]. The COVID 19 virus disseminates through the cribriform plate and olfactory bulb as well as trans-synaptic transfer . The refractory respiratory failure seen in critically-ill COVID-19 patients may be due to invasion of the medullary cardiorespiratory center by the virus [162]. The most common reported neurological symptoms are headache, hyposmia, weakness, altered consciousness, encephalopathy and delirium. Neurological complications include Cerebrovascular accident, acute encephalitis, Guillian barre syndrome and acute transverse myelitis. Neurological manifestations can precede the typical COVID 19 symptoms [160,162].

\section{CUTANEOUS MANIFESTATIONS OF COVID 19}

The dermatologic manifestations associated with COVID-19 are many, nonspecific and varied. Nearly all patients could be classified in these groups, and a few unusual cases are seen [146]. 
1.-Acral areas of erythema-oedema with some vesicles or pustules (pseudo-chilblain) (19\% of cases). These lesions may resemble chilblains and have purpuric areas; affecting hands and feet.They were usually asymmetrical [147].

2.-Other vesicular eruptions (9\%). Some presented on the trunk and consisted of small monomorphic vesicles (unlike polymorphic vesicles in chickenpox). They may also affect the limbs, have haemorrhagic content, and become larger or diffuse [148].

3.- Urticarial lesions (19\%): mostly distributed in the trunk or disperse. A few cases were palmar [150].

4.- Other maculopapules (47\%). Some of them showed perifollicular distribution and varying degrees of scaling. Some had been described as similar to pityriasis rosea. Purpura may also be present, either punctiform or on larger areas [151]. A few cases showed infiltrated papules in the extremities, mostly dorsum of the hands, that look pseudovesicular or resemble erythema elevatum diutinum or erythema multiforme [152].

5.- Livedo or necrosis (6\%). These patients showed different degrees of lesions suggesting occlusive vascular disease, including areas of truncal or acral ischemia [149].

The mechanisms of COVID-19 cutaneous disturbances are not yet well known, but some common theories are prevalent [153]. It can be postulated that the viral particles present in the cutaneous blood vessels in patients with COVID19 infection could lead to a lymphocytic vasculitis similar to those observed in thrombophilic arteritis induced by blood immune complexes that activate cytokines [154]. Keratinocytes may be a secondary target after Langerhans cells activation, inducing a spectrum of different clinical manifestation [155]. It can be postulated that the virus does not target the keratinocyte, but rather immune response to infection leads to Langerhans cells activation, resulting in a state of vasodilation and spongiosis. Further theories suggest livedo reticularis-resembling manifestations can result due the accumulation of microthromboses originating in other organs, thus reducing blood flow to the cutaneous microvasculature system [156]. Similarly, low grade disseminated intravascular coagulation and hypoxia-related accumulation of deoxygenated blood in venous plexes may further explain such manifestations
[157]. Additionally, pauci-inflammatory thrombogenic vasculopathy with deposition of C5b-9 and C4d as well as co-localization of these with COVID-19 spike glycoproteins [158]. It is still unclear whether cutaneous symptoms are a secondary consequence of respiratory-related infection or a primary infection of the skin itself. It is more likely that a combination of such mechanisms is responsible for the cutaneous manifestations found in COVID-19+ individuals [159].

POST-VIRAL SYNDROME POST COVID-19

Perrin et al proposed that once an acute COVID19 infection has been overcome, a subgroup of remitted patients are likely to experience longterm adverse effects resembling Chronic Fatigue Syndrome/Myalgic Encephalomyelitis (CFS/ME) symptomatology such as persistent fatigue, diffuse myalgia, depressive symptoms, and non-restorative sleep [167].Also George et al stated that data from previous coronavirus infections such as severe acute respiratory syndrome and Middle East respiratory syndrome, as well as emerging data from the COVID-19 pandemic, suggest there could be substantial fibrotic consequences following SARS-CoV-2 infection[168].

Acknowledgment: We thank Dr Waheed Shouman ; Professor of Chest Diseases ,Faculty of Medicine ,Zagazig University for his clinical suggestions about the use of ivermectin in both treatment and prophylaxis of Covid 19.

\section{Conflict of interest and Funding: None}

\section{REFERENCES}

1. Li Q, Guan X, Wu P, Wang X Zhou, L Tong Y, et al. Early transmission dynamics in Wuhan, China, of novel coronavirus-infected pneumonia. N Engl J Med 2020 26; 382(13):1199-1207.

2. World Health Organization Director-General's opening remarks at the media briefing on COVID-19 - 24 February 2020 https://www.who.int/dg/speeches/detail/whodirector-general-s-opening-remarks-at-themedia-briefing-on-covid-19---24-february-2020 (Accessed on February 26, 2020).

3. World Health Organization Director-General's opening remarks at the media briefing on COVID-19-11 March 2020 https://www.who.int/dg/speeches/detail/whodirector-general-s-opening-remarks-at-themedia-briefing-on-covid-19---11-March-2020 (Accessed on March 12, 2020). 
4. Chan JF, Lau SK, To KK, Cheng VC, Woo PC, Yuen K.-Y. Middle East respiratory syndrome coronavirus: another zoonotic betacoronavirus causing SARS-like disease. Clin. Microbiol. Rev 2015; 28:465-522

5. Elfiky AA, Mahdy SM, Elshemey WM. Quantitative structure-activity relationship and molecular docking revealed a potency of antihepatitis $\mathrm{C}$ virus drugs against human corona viruses. J Med Virol 2017; 89:1040-1047.

6. Hui DS, Azhar IE, Madani TA, Ntoumi F, Kock R, DarO, et al. The continuing 2019nCoV epidemic threat of novel coronaviruses to global health - the latest 2019 novel coronavirus outbreak in Wuhan, China. International Journal of Infectious Diseases 2020; 91:264-26.

7. Hoffman M, Kliene-Weber H, Krüger N, Herrler T, Erichsen S, Schiergens TS, et al. SARS-CoV2 Cell Entry Depends on ACE2 and TMPRSS2 and Is Blocked by a Clinically Proven Protease Inhibitor. Cell 2020; 181(2):271-280.e8.

8. Masters PS. The molecular biology of coronaviruses. Adv Virus Res 2006; 66:193- 292.

9. Shang J, Wan Y, Luo C, Ye G, Geng Q, Auerbach A et al. Cell entry mechanisms of SARS-CoV-2 [published online ahead of print, 2020 May 6]. Proc Natl Acad Sci U S A. 2020;202003138. doi:10.1073/pnas.2003138117

10. Tang X, Wu C, Li X, Song Y, Yao X, Wu X, et al. On the origin and continuing evolution of SARS-CoV-2, National Science Review, nwaa036, https://doi.org/10.1093/nsr/nwaa036.

11. Xiao F, Tang M, Zheng X, Liu Y, Li X, Shan H. Evidence for Gastrointestinal Infection of SARS-CoV-2. Gastroenterology 2020; 158(6): 1831-1833.e3.

12. de Wit E, van Doremalen N, Falzarano D, Munster VJ. SARS and MERS: recent insights into emerging coronaviruses. Nat Rev Microbiol 2016; 14(8): 523-534.

13. Li W, Moore MJ, Vasilieva N, Sui J, Wong SK, Berne MA et al. Angiotensin-converting enzyme 2 is a functional receptor for the SARS coronavirus. Nature 2003 Nov 27; 426(6965): 450-4.

14. Jeffers SA, Tusell SM, Gillim-Ross L, Hemmila EM, Achenbach JE, Babcock GJ, et al. CD209L (L-SIGN) is a receptor for severe acute respiratory syndrome coronavirus. Proc Natl Acad Sci USA 2004; 101(44): 15748-53.

15. Raj VS, Mou H, Smits SL, Dekkers DH, Müller MA, Dijkman R, et al. Dipeptidyl peptidase 4 is a functional receptor for the emerging human coronavirus-EMC. Nature 2013; 495(7440):2514.

16. Wu F, Zhao S, Yu B, Chen YM, Wang W, Song $\mathrm{ZG}$, et al. A new coronavirus associated with human respiratory disease in China. Nature 2020; 579(7798): 265-269.
17. Millet JK, Whittaker GR. Host cell entry of Middle East respiratory syndrome coronavirus after two-step, furin-mediated activation of the spike protein. Proc Natl Acad Sci USA 2014; 111(42):15214-9.

18. Wang H, Yang $\mathrm{P}$, Liu K, Guo F, Zhang Y, Zhang G, et al. SARS coronavirus entry into host cells through a novel clathrin- and caveolaeindependent endocytic pathway. Cell Res 2008;18(2):290-301.

19. Kuba K, Imai Y, Ohto-Nakanishi T, Penninger JM. Trilogy of ACE2: a peptidase in the reninangiotensin system, a SARS receptor, and a partner for amino acid transporters. Pharmacol Ther 2010;128(1):119-28.

20. Perlman S, Netland J. Coronaviruses postSARS: update on replication and pathogenesis. Nat Rev Microbiol 2009;7(6):439-50.

21. Liu J, Wu P, Gao F, Qi J, Kawana-Tachikawa A, Xie $\mathrm{J}$, et al. Novel immunodominant peptide presentation strategy: a featured HLA-A $* 2402$ restricted cytotoxic T-lymphocyte epitope stabilized by intrachain hydrogen bonds from severe acute respiratory syndrome coronavirus nucleocapsid protein. J Virol 2010;85:1184911857

22. Hajeer AH, Balkhy H, Johani S, Yousef MZ, Arabi Y. Association of human leukocyte antigen class II alleles with severe Middle East respiratory syndrome-coronavirus infection. Ann Thorac Med 2016; 11(3): 211-3.

23. Xu Z, Shi L, Wang Y, Zhang J, Huang L, Zhang $\mathrm{C}$, et al. Pathological findings of COVID-19 associated with acute respiratory distress syndrome. Lancet Respir Med 2020; 8(4):420422.

24. Rothan HA, Byrareddy SN. The epidemiology and pathogenesis of coronavirus disease (COVID-19) outbreak. J Autoimmun 2020; 109:102433.

25. Channappanavar R, Fehr AR, Vijay R, Mack M, Zhao J, Meyerholz DK, et al. Dysregulated Type I Interferon and Inflammatory MonocyteMacrophage Responses Cause Lethal Pneumonia in SARS-CoV-Infected Mice. Cell Host Microbe 2016;19(2):181-93.

26. Channappanavar R, Fehr AR, Zheng J, Wohlford-Lenane C, Abrahante JE, Mack M, et al. IFN-I response timing relative to virus replication determines MERS coronavirus infection outcomes. J Clin Invest 2019; 130(9):3625-3639.

27. Patel AB, Verma A. COVID-19 and Angiotensin-Converting Enzyme Inhibitors and Angiotensin Receptor Blockers: What Is the Evidence? [published online ahead of print, 2020 Mar 24]. JAMA 2020;10.1001/jama.2020.4812. doi:10.1001/jama.2020.4812.

28. Zhou P, Yang XL, Wang XG, Hu B, Zhang L, Zhang $\mathrm{W}$, et al. A pneumonia outbreak 
associated with a new coronavirus of probable bat origin. Nature 2020; 579(7798):270-273.

29. Kuba K, Imai Y, Rao S, Gao H, Guo F, Guan B, et al. A crucial role of angiotensin converting enzyme 2 (ACE2) in SARS coronavirus-induced lung injury. Nat Med 2005; 11(8):875-9.

30. American Heart Association. HFSA/ACC/AHA statement addresses concerns re: using RAAS antagonists in COVID-19. Accessed March 20, 2020. Available at: https://www.acc.org/latestin-cardiology/articles/2020/03/17/08/59/hfsaacc-aha-statement-addresses-concerns-re-usingraas-antagonists-in-covid-19.

31. Zhang Y, Xiao M, Zhang S, Xia P, Cao W, Jiang W, et al. Coagulopathy and Antiphospholipid Antibodies in Patients with Covid-19. N Engl J Med 2020 Apr 23;382(17):e38.

32. Zhu N, Zhang D, Wang W, Li X, Yang B, Song $\mathrm{J}$, et al. A novel coronavirus from patients with pneumonia in China, 2019. $N$ Engl $J$ Med 2020;382(8):727-733.

33. Magro C, Mulvey JJ, Berlin D, Nuovo G, Salvatore S, Harp J, et al. Complement associated microvascular injury and thrombosis in the pathogenesis of severe COVID-19 infection: a report of five cases. Transl Res 2020 Apr 15:S1931-5244(20)30070-0.

34. Rotzinger DC, Beigelman-Aubry C, von Garnier C, Qanadli SD. Pulmonary embolism in patients with COVID-19: Time to change the paradigm of computed tomography. Thromb Res 2020; 190:58-59.

35. Paraskevis D, Kostaki EG, Magiorkinis G, Panayiotakopoulos G, Sourvinos G, Tsiodras S. Full-genome evolutionary analysis of the novel corona virus (2019-nCoV) rejects the hypothesis of emergence as a result of a recent recombination event. Infect Genet Evol 2020; 79:104212.

36. Giovanetti $\mathrm{M}$, Benvenuto $\mathrm{D}$, Angeletti $\mathrm{S}$, Ciccozzi M. The first two cases of 2019-nCoV in Italy: where they come from? J Med Virol 2020:1-4. 10.1002/jmv.25699

37. Liu Z, Xiao X, Wei X, Li J, Yang J, Tan H, Zhu J, Zhang Q, Wu J, Liu L. Composition and divergence of coronavirus spike proteins and host ACE2 receptors predict potential intermediate hosts of SARS-CoV-2. J Med Virol 2020 Feb 26:10.1002/jmv.25726. doi: 10.1002/jmv.25726. Epub ahead of print.

38. Guan WJ, Ni ZY, Hu Y, Liang WH, Ou CQ, He JX, et al. Clinical Characteristics of Coronavirus Disease 2019 in China. N Engl J Med 2020; 382(18): 1708-1720.

39. Rothe C, Schunk M, Sothmann P, Bretzel G, Froeschl G, Wallrauch $\mathrm{C}$, et al. Transmission of 2019-nCoV Infection from an Asymptomatic Contact in Germany. N Engl J Med 2020; 382(10): 970-971.
40. Guo YR, Cao QD, Hong ZS, Tan YY, Chen SD, Jin HJ, et al. The origin, transmission and clinical therapies on coronavirus disease 2019 (COVID-19) outbreak - an update on the status. Mil Med Res 2020 Mar 13; 7(1):11.

41. World Health Organization. Situation reports. Available

at: https://www.who.int/emergencies/diseases/no vel-coronavirus-2019/situation-reports/.

Accessed 22 Feb 2020.

42. Zou L, Ruan F, Huang M, Liang L, Huang H, Hong Z, et al. SARS-CoV-2 Viral Load in Upper Respiratory Specimens of Infected Patients. N Engl J Med 2020 Mar 19;382(12):1177-1179.

43. Kampf G, Todt D, Pfaender S, Steinmann E. Persistence of coronaviruses on inanimate surfaces and their inactivation with biocidal agents. J Hosp Infect 2020 Mar; 104(3):246-251

44. Chen H, Guo J, Wang C, Luo F, Yu X, Zhang $\mathrm{W}$, et al. Clinical characteristics and intrauterine vertical transmission potential of COVID-19 infection in nine pregnant women: a retrospective review of medical records. Lancet 2020 Mar 7; 395(10226):809-815.

45. Wang D, Hu B, Hu C, Zhu F, Liu X, Zhang J, et al. Clinical Characteristics of 138 Hospitalized Patients With 2019 Novel Coronavirus-Infected Pneumonia in Wuhan, China. JAMA 2020 Feb 7;323(11):1061-9.

46. Cheng ZJ, Shan J. 2019 Novel coronavirus: where we are and what we know. Infection 2020; 48(2):155-163.

47. Cowling BJ, Lau MS, Ho LM, Chuang SK, Tsang T, Liu SH, et al. The effective reproduction number of pandemic influenza: prospective estimation. Epidemiology 2010; 21(6): 842-6.

48. Chan JF, Yuan S, Kok KH, To KK, Chu H, Yang J, et al. A familial cluster of pneumonia associated with the 2019 novel coronavirus indicating person-to-person transmission: a study of a family cluster. Lancet 2020 ;395(10223):514-523.

49. Bajema KL, Oster AM, McGovern OL, Lindstrom S, Stenger MR, Anderson TC, et al. Persons Evaluated for 2019 Novel Coronavirus United States, January 2020. MMWR Morb Mortal Wkly Rep 2020; 69(6):166-170.

50. Wu Z, McGoogan JM. Characteristics of and Important Lessons From the Coronavirus Disease 2019 (COVID-19) Outbreak in China: Summary of a Report of 72314 Cases From the Chinese Center for Disease Control and Prevention. JAMA 2020; 10.1001/jama.2020.2648. doi:10.1001/jama.2020.2648.

51. Zhou F, Yu T, Du R, Fan G, Liu Y, Liu Z, et al. Clinical course and risk factors for mortality of adult inpatients with COVID-19 in Wuhan, 
China: a retrospective cohort study. Lancet 2020; 395:1054.

52. Liang W, Guan W, Chen R, Wang W, Li J, Xu $\mathrm{K}$, et al. Cancer patients in SARS-CoV-2 infection: a nationwide analysis in China. Lancet Oncol 2020 Mar;21(3):335-337.

53. CDC COVID-19 Response Team. Preliminary Estimates of the Prevalence of Selected Underlying Health Conditions Among Patients with Coronavirus Disease 2019 - United States, February 12-March 28, 2020. MMWR Morb Mortal Wkly Rep 2020; 69(13):382-386.

54. Centers for Disease Control and Prevention. People who are at higher risk for severe illness https://www.cdc.gov/coronavirus/2019ncov/need-extra-precautions/people-at-higherrisk.html (Accessed on April 01, 2020).

55. Japanese National Institute of Infectious Diseases. Field Briefing: Diamond Princess COVID-19 Cases, 20 Feb Update. https://www.niid.go.jp/niid/en/2019-ncove/9417-covid-dp-fe-02.html (Accessed on March 01, 2020).

56. Hu Z, Song C, Xu C, Jin G, Chen Y, Xu X, et al. Clinical characteristics of 24 asymptomatic infections with COVID-19 screened among close contacts in Nanjing, China. Sci China Life Sci 2020; 63(5):706-711.

57. Wang Y, Liu Y, Liu L, Wang X, Luo N, Li L. Clinical Outcomes in 55 Patients With Severe Acute Respiratory Syndrome Coronavirus 2 Who Were Asymptomatic at Hospital Admission in Shenzhen, China. J Infect Dis 2020; 221(11):1770-1774.

58. Escalera-Antezana JP, Lizon-Ferrufino NF, Maldonado-Alanoca A, Alarcón-De-la-Vega G, Alvarado-Arnez LE, Balderrama-Saavedra MA, et al. Clinical features of the first cases and a cluster of Coronavirus Disease 2019 (COVID19) in Bolivia imported from Italy and Spain. Travel Med Infect Dis 2020 Apr 2:101653.

59. Huang C, Wang Y, Li X, Ren L, Zhao J, Hu Y, et al. Clinical features of patients infected with 2019 novel coronavirus in Wuhan, China. Lancet 2020;395(10223):497-506.

60. Guan WJ, Ni ZY, Hu Y, Liang WH, Ou CQ, He JX, et al. Clinical Characteristics of Coronavirus Disease 2019 in China. N Engl J Med 2020; 382(18):1708-1720.

61. Giacomelli A, Pezzati L, Conti F, Bernacchia D, Siano M, Oreni L, et al. Self-reported olfactory and taste disorders in SARS-CoV-2 patients: a cross-sectional study. Clin Infect Dis 2020 Mar 26:ciaa330.

62. Jin X, Lian JS, Hu JH, Gao J, Zheng L, Zhang YM, et al. Epidemiological, clinical and virological characteristics of 74 cases of coronavirus-infected disease 2019 (COVID-19) with gastrointestinal symptoms. Gut 2020;69(6):1002-1009.
63. WHO: https://www.who.int/docs/defaultsource/coronaviruse/who-china-joint-missiononcovid-19-final-report.pdf.

64. European CDC: https://www.ecdc.europa.eu/en/case-definitionand-european-surveillance-human-infectionnovel-coronavirus-2019-ncov.

65. Huang P, Liu T, Huang L, Liu H, Lei M, Xu W, et al. Use of Chest CT in Combination with Negative RT-PCR Assay for the 2019 Novel Coronavirus but High Clinical Suspicion. Radiology 2020; 295(1): 22-23.

66. CDC: https://www.cdc.gov/coronavirus/2019nCoV/lab/guidelines-clinical-specimens.html. Accessed 16 March 2020).

67. Wahidi MM, Lamb C, Murgu S, Musani A, Shojaee S, Sachdeva A, et al. American Association for Bronchology and Interventional Pulmonology (AABIP) Statement on the Use of Bronchoscopy and Respiratory Specimen Collection in Patients with Suspected or Confirmed COVID-19 Infection. J Bronchology Interv Pulmonol $2020 \quad$ Mar 18:10.1097/LBR.0000000000000681.

68. To KK, Tsang OT, Chik-Yan Yip C, Chan KH, $\mathrm{Wu}$ TC, Chan JMC, et al. Consistent detection of 2019 novel coronavirus in saliva. Clin Infect Dis 2020 Feb 12:ciaa149. doi: 10.1093/cid/ciaa149.

69. Holshue ML, DeBolt C, Lindquist S, Lofy KH, Wiesman J, Bruce H, et al. First Case of 2019 Novel Coronavirus in the United States. $N$ Engl J Med 2020;382(10):929-936.

70. CDC: (https://www.fda.gov/media/134922/ download) Accessed 15 March 2020).

71. Ksiazek TG, Erdman D, Goldsmith CS, Zaki SR, Peret T, Emery S, et al. A novel coronavirus associated with severe acute respiratory syndrome. N Engl J Med 2003; 348(20): 19531966.

72. Li Z, Yi Y, Luo X, Xiong N, Liu Y, Li S, et al. Development and clinical application of a rapid IgM-IgG combined antibody test for SARSCoV-2 infection diagnosis. J Med Virol 2020 Feb 27:10.1002/jmv.25727. doi: 10.1002/jmv.25727. Epub ahead of print. PMID: 32104917 ; PMCID: PMC7228300.

73. Zhao J, Yuan Q, Wang H, Liu W, Liao X, Su Y, et al. Antibody responses to SARS-CoV-2 in patients of novel coronavirus disease 2019. Clin Infect Dis 2020 Mar 28:ciaa344. doi: 10.1093/cid/ciaa344. Epub ahead of print. PMID: 32221519; PMCID: PMC7184337.

74. Xie X, Zhong Z, Zhao W, Zheng C, Wang F, Liu J. Chest CT for Typical 2019-nCoV Pneumonia: Relationship to Negative RT-PCR Testing [published online ahead of print, $2020 \mathrm{Feb} 12$ ]. Radiology 2020; 200343. doi:10.1148/radiol.2020200343.

75. Jin YH, Cai L, Cheng ZS, Cheng H, Deng T, Fan YP, et al. A rapid advice guideline for the 
diagnosis and treatment of 2019 novel coronavirus (2019-nCoV) infected pneumonia (standard version). Mil Med Res 2020; 7(1):4.

76. Lei P, Fan B, Wang P. Differential Diagnosis for Coronavirus Disease (COVID-19): Beyond Radiologic Features [published online ahead of print, 2020 Apr 2]. AJR Am J Roentgenol 2020; W1. doi:10.2214/AJR.20.23119.

77. Bouadma L, Lescure FX, Lucet JC, Yazdanpanah Y, Timsit JF. Severe SARS-CoV2 infections: practical considerations and management strategy for intensivists. Intensive Care Med 2020; 46(4):579-582.

78. Wang M, Cao R, Zhang L, Yang X, Liu J, Xu $\mathrm{M}$, et al. Remdesivir and chloroquine effectively inhibit the recently emerged novel coronavirus (2019-nCoV) in vitro. Cell Res 2020; 30(3):269271.

79. Savarino A, Di Trani L, Donatelli I, Cauda R, Cassone A. New insights into the antiviral effects of chloroquine. Lancet Infect Dis 2006; 6(2):67-9.

80. Colson P, Rolain JM, Raoult D. Chloroquine for the 2019 novel coronavirus SARS-CoV-2. Int J Antimicrob Agents 2020; 55(3):105923.

81. Yao X, Ye F, Zhang M, Cui C, Huang B, Niu P, et al. In Vitro Antiviral Activity and Projection of Optimized Dosing Design of Hydroxychloroquine for the Treatment of Severe Acute Respiratory Syndrome Coronavirus 2 (SARS-CoV-2). Clin Infect Dis 2020 Mar 9:ciaa237.

82. IDEACOVID-19 treatment available at: https://covid.idea.medicine.uw.edu/page/treatme nt/guidance

83. Mehra RM, Desai SS, Ruschitzka F, Patel NA. Hydroxychloroquine or chloroquine with or without a macrolide for treatment of COVID-19: a multinational registry analysis. The Lancet. Published: $\quad$ May 22, 2020. DOI:https://doi.org/10.1016/S01406736(20)31180-6.

84. Arabi YM, Asiri AY, Assiri AM, Aziz Jokhdar HA, Alothman A, Balkhy HH, et al. Treatment of Middle East respiratory syndrome with a combination of lopinavir/ritonavir and interferon- $\beta 1 \mathrm{~b}$ (MIRACLE trial): statistical analysis plan for a recursive two-stage group sequential randomized controlled trial. Trials 2020; 21(1):8.

85. Adopted from https://www.uptodate.com/ contents/favipiravir.

86. Arabi YM, Shalhoub S, Mandourah Y, AlHameed F, Al-Omari A, Al Qasim E, et al. Ribavirin and Interferon Therapy for Critically Ill Patients With Middle East Respiratory Syndrome: A Multicenter Observational Study. Clin Infect Dis 2020; 70(9):1837-1844.

87. Zhang C, Wu Z, Li JW, Zhao H, Wang GQ. The cytokine release syndrome (CRS) of severe
COVID-19 and Interleukin-6 receptor (IL-6R) antagonist Tocilizumab may be the key to reduce the mortality. Int $J$ Antimicrob Agents 2020:105954. doi: 10.1016/j.ijantimicag.

88. Mehta P, McAuley DF, Brown M, Sanchez E, Tattersall RS, Jessica J, et al. COVID-19: consider cytokine storm syndromes and immunosuppression. Lancet 2020; 395(10229): 1033-1034.

89. Liu B, Li M, Zhou Z, Guan X, Xiang Y. Can we use interleukin-6 (IL-6) blockade for coronavirus disease 2019 (COVID-19)-induced cytokine release syndrome (CRS)? J Autoimmun 2020 Apr 10:102452. doi: 10.1016/j.jaut.2020.102452.

90. Adopted from: http://www.med.umich.edu/ asp/pdf/adult guidelines/COVID-19treatment.pdf.

91. Chen L, Xiong J, Bao L, Shi Y. Convalescent plasma as a potential therapy for COVID-19. Lancet Infect Dis 2020; 20(4):398-400. doi: 10.1016/S1473-3099(20)30141-9.

92. Roback JD, Guarner J. Convalescent Plasma to Treat COVID-19: Possibilities and Challenges [published online ahead of print, 2020 Mar 27]. JAMA 2020;10.1001/jama.2020.4940. doi:10.1001/jama.2020.4940.

93. Lee AYY, Connors JM, Kreuziger LB, Murphy M, Gernsheimer T, Lin Y. COVID-19 and Coagulopathy: Frequently Asked Questions; American society of hematology/Covid-19 resources; Version 1.0; last updated April 1, 2020.

94. Gbinigie K, Frie K. Should azithromycin be used to treat COVID-19? A rapid review [published online ahead of print, 2020 May 12]. BJGP Open. 2020;bjgpopen20X101094. doi:10.3399/bjgpopen20X101094.

95. Russell CD, Millar JE, Baillie JK. Clinical evidence does not support corticosteroid treatment for 2019-nCoV lung injury. Lancet 2020 Feb 15;395(10223):473-475.

96. Yang X, Yu Y, Xu J, Shu H, Xia J, Liu H, et al. Clinical course and outcomes of critically ill patients with SARS-CoV-2 pneumonia in Wuhan, China: a single-centered, retrospective, observational study. Lancet Respir Med 2020 May;8(5):475-481.

97. Hemilä H. Vitamin C and SARS coronavirus. $J$ Antimicrob Chemother 2003; 52(6):1049-50.

98. Grant WB, Lahore H, McDonnell SL, Baggerly CA, French CB, Aliano JL, et al. Evidence that Vitamin D Supplementation Could Reduce Risk of Influenza and COVID-19 Infections and Deaths. Nutrients 2020;12(4):988.

99. te Velthuis AJ, van den Worm SH, Sims AC, Baric RS, Snijder EJ, van Hemert MJ. Zn(2+) inhibits coronavirus and arterivirus RNA polymerase activity in vitro and zinc ionophores block the replication of these viruses in cell culture. PLoS Pathog 2010;6(11):e1001176. 
100. Anderson G, Reiter RJ. Melatonin: Roles in influenza, Covid-19, and other viral infections. Rev Med Virol 2020; 30(3): 2109.

101. Zhou F, Yu T, Du R, Fan G, Liu Y, Liu Z et al. Clinical course and risk factors for mortality of adult inpatients with COVID-19 in Wuhan, China: a retrospective cohort study [published correction appears in Lancet. 2020 Mar 28; 395(10229):1038] Lancet. 2020; 395(10229): 1054-1062.

102. Meng J, Xiao G, Zhang J, He X, Ou M, Bi J, et al. Renin-angiotensin system inhibitors improve the clinical outcomes of COVID-19 patients with hypertension. Emerg Microbes Infect. 2020;9(1):757-760.

103. Little P. Non-steroidal anti-inflammatory drugs and covid-19. BMJ 2020;368:m1185.

104. Wu Z, McGoogan JM. Characteristics of and Important Lessons From the Coronavirus Disease 2019 (COVID-19) Outbreak in China: Summary of a Report of 72314 Cases From the Chinese Center for Disease Control and Prevention [published online ahead of print, 2020 Feb 24]. JAMA. 2020; 10.1001/jama.2020.2648. doi:10.1001/jama.2020.2648

105. Yang X, Yu Y, Xu J, Shu H, Xia J, Liu H, et al. Clinical course and outcomes of critically ill patients with SARS-CoV-2 pneumonia in Wuhan, China: a single-centered, retrospective, observational study. Lancet Respir Med 2020; $8(5): 475-481$.

106. WHO: Clinical management of severe acute respiratory infection ( SARI ) when COVID-19 disease is suspected," vol. 2019, no. December 2019, 2020.

107. Wu C, Chen X, Cai Y, Xia J, Zhou X, Xu S, et 1. Risk Factors Associated With Acute Respiratory Distress Syndrome and Death in Patients With Coronavirus Disease 2019 Pneumonia in Wuhan, China. JAMA Intern Med 2020 Mar 13:e200994.

108. Combes A, Hajage D, Capellier G, Demoule A, Lavoue S, Guervilly C, et al. Extracorporeal membrane oxygenation for severe acute respiratory distress syndrome. $N$ Engl $\mathrm{J} \mathrm{Med}$ 2018; 378(21):1965-1975.

109. Goligher EC, Tomlinson G, Hajage D, Wijeysundera DN, Fan E, Jüniet $\mathrm{P}$ et al. Extracorporeal Membrane Oxygenation for Severe Acute Respiratory Distress Syndrome and Posterior Probability of Mortality Benefit in a Post Hoc Bayesian Analysis of a Randomized Clinical Trial [published correction appears in JAMA. 2019 Jun 11;321(22):2245]. JAMA. 2018; 320(21):22 51-2259.

110. Alshahrani MS, Sindi A, Alshamsi F, Al-Omari A, El Tahan M, Alahmadi B, et la. Extracorporeal membrane oxygenation for severe Middle East respiratory syndrome coronavirus. Ann Intensive Care 2018 Jan 10; $8(1): 3$

111. Combes A, Brodie D, Bartlett R, Brochard L, Brower R, Conrad S, et al. Position paper for the organization of extracorporeal membrane oxygenation programs for acute respiratory failure in adult patients. Am J Respir Crit Care Med 2014; 190(5):488-496.

112. Munshi L, Walkey A, Goligher E, Pham T, Uleryk EM, Fan E. Venovenous extracorporeal membrane oxygenation for acute respiratory distress syndrome: a systematic review and meta-analysis. Lancet Respir Med 2019; 7(2): 163-172.

113. CDC. Interim Clinical Guidance for Management of Patients with Confirmed Corona virus Disease (COVID-19): https://www.cdc.gov/coronavirus/2019ncov/hcp/clinical-guidance-managementpatients.html

114. CDC. Coronavirus Disease 2019 (COVID-19), Discontinuation of Transmission-Based Precautions and Disposition of Patients with COVID-19 in Healthcare Settings (Interim Guidance):https://www.cdc.gov/coronavirus/201 9-ncov/hcp/disposition-hospitalizedpatients.html

115. Italian Ministry of health: http://www.salute.gov.it/portale/ministro/p4_5_2 7.jsp?lingua $=$ italiano\&label=consigliosuperiore sanita\&menu=consigliosuperioresanita

116. ECDC TECHNICAL REPORT, Novel coronavirus (SARS-CoV-2) Discharge criteria for confirmed COVID-19 cases - When is it safe to discharge COVID-19 cases from the hospital or end home isolation?

117. Chinese CD. Available at: https://www.chinadaily.com.cn/pdf/2020/1.Clini cal.Protocols.for.the.Diagnosis.and.Treatment.of .COVID-19.V7.pdf

118. Tay JY, Lim PL, Marimuthu K, Sadarangani SP, Ling LM, Anget PSP et al. De-isolating COVID19 Suspect Cases: A Continuing Challenge [published online ahead of print, 2020 Feb 26]. Clin Infect Dis 2020; ciaa179. doi:10.1093/cid/ciaa179.

119. Anderson RM, Heesterbeek H, Klinkenberg D, Hollingsworth TD. How will country-based mitigation measures influence the course of the COVID-19 epidemic? Lancet 2020 Mar 21;395(10228):931-934.

120. WHO. https://www.who.int/who-documentsdetail/criteria-for-covid-19-vaccine-prioritization

121. World Health Organization. "Advice for Public". Archived from the original on 26 January 2020. Retrieved 10 February 2020.

122. Centers for Disease Control (3 February 2020). "Coronavirus Disease 2019 (COVID-19): Prevention \& Treatment". Archived from the 
original on 15 December 2019. Retrieved 10 February 2020

123. Alhazzani W, Møller MH, Arabi YM, Loeb M, Gong MN, Fan E, et al. Surviving Sepsis Campaign: Guidelines on the Management of Critically Ill Adults with Coronavirus Disease 2019 (COVID-19). Crit Care Med 2020; 48(6):e440-e469.

124. Health Commission of the People's Republic of China (2012). The standardization for sterilization techniques in hospital. Retrieved from http://www.nhc.gov.cn/wjw/s9496/201204/ 54510.shtml. Accessed March 11, 2020.

125. Shi S, Qin M, Shen B, Cai Y, Liu T, Yang F, et al. Association of Cardiac Injury With Mortality in Hospitalized Patients With COVID-19 in Wuhan, China. JAMA Cardiol 2020 Mar 25:e200950. doi: 10.1001/jamacardio. 2020. 0950. Epub ahead of print. PMID: 32211816; PMCID: PMC7097841.

126. Ruan Q, Yang K, Wang W, Jiang L, Song J. Clinical predictors of mortality due to COVID19 based on an analysis of data of 150 patients from Wuhan, China. Intensive Care Med 2020; 46(5):846-848.

127. Guo T, Fan Y, Chen M, Wu X, Zhang L, He T, et al.. Cardiovascular Implications of Fatal Outcomes of Patients With Coronavirus Disease 2019 (COVID-19). JAMA Cardiol 2020 Mar 27:e201017.

128. Estabragh ZR, Mamas MA. The cardiovascular manifestations of influenza: a systematic review. Int J Cardiol 2013;167(6): 2397-2403.

129. Zhou F, Yu T, Du R, Fan G, Liu Y, Liu Z et al. Clinical course and risk factors for mortality of adult inpatients with COVID-19 in Wuhan, China: a retrospective cohort study [published correction appears in Lancet. 2020; 395(10229):1038] .

130. Arentz M, Yim E, Klaff L, Lokhandwala S, Riedo FX, Chong M, et al. Characteristics and Outcomes of 21 Critically Ill Patients With COVID-19 in Washington State. JAMA 2020;323(16):1612-4.

131. Inciardi RM, Lupi L, Zaccone G, Italia L, Raffo $\mathrm{M}$, Tomasoni D, et al. Cardiac Involvement in a Patient With Coronavirus Disease 2019 (COVID-19) [published online ahead of print, 2020 Mar 27]. JAMA Cardiol. 2020;10.1001/jamacardio.2020.1096. doi:10.1001/jamacardio.2020.1096.

132. Hu H, Ma F, Wei X, Fang Y. Coronavirus fulminant myocarditis saved with glucocorticoid and human immunoglobulin. Eur Heart J. 2020 Mar 16:ehaa190.

133. Atri D, Siddiqi HK, Lang J, Nauffal V, Morrow DA, Bohula EA. COVID-19 for the Cardiologist: A Current Review of the Virology, Clinical Epidemiology, Cardiac and Other Clinical Manifestations and Potential
Therapeutic Strategies. JACC Basic Transl Sci 2020 Apr 10. doi: 10.1016/j.jacbts.2020.04.002. Epub ahead of print. PMID: 32292848; PMCID: PMC7151394.

134. Chai X, Hu L, Zhang Y, Han W, Lu Z, Ke A, et al. Specific ACE2 Expression in Cholangiocytes May Cause Liver Damage After 2019-nCoV Infection. Bio Rxiv 2020.02.03.931766; doi: https://doi.org/10.1101/2020.02.03.931766.

135. Xu Z, Shi L, Wang Y, Zhang J, Huang L, Zhang $\mathrm{C}$, et al. Pathological findings of COVID-19 associated with acute respiratory distress syndrome. Lancet Respir Med 2020;8(4):420422.

136. Shi H, Han X, Jiang N, Cao Y, Alwalid O, Gu J, et al. Radiological findings from 81 patients with COVID-19 pneumonia in Wuhan, China: a descriptive study. Lancet Infect Dis 2020;20(4):425-434.

137. Cai Q, Huang D, Ou P, Yu H, Zhu Z, Xia Z, et al. COVID-19 in a designated infectious diseases hospital outside Hubei Province, China [published online ahead of print, 2020 Apr 2]. Allergy. 2020;10.1111/all.14309. doi:10.1111/all.14309.

138. Soetikno R, Teoh AY, Kaltenbach T, Lau JY, Asokkumar R, Cabral-Prodigalidad P, et al.. Considerations in performing endoscopy during the COVID-19 pandemic. Gastrointest Endosc 2020 Mar 27:S0016-5107(20)34033-5.

139. Gu J, Han B, Wang J. COVID-19: Gastrointestinal Manifestations and Potential Fecal-Oral Transmission. Gastroenterology 2020; 158(6):1518-1519.

140. World Endoscopy Organization: WEO advice to endoscopists. $\quad 2020$. http://www.worldendo.org/2020/03/24/weoadvice-on-digestive-endoscopy-and-the-covid19-pandemic/.

141. Chiu PWY, Ng SC, Inoue H, Reddy DN, Ling $\mathrm{Hu}$ E, Cho JY, et al. Practice of endoscopy during COVID-19 pandemic: position statements of the Asian Pacific Society for Digestive Endoscopy (APSDE-COVID statements). Gut 2020 Jun;69(6):991-996.

142. Repici A, Maselli R, Colombo M, Gabbiadini R, Spadaccini M, Anderloni A, et al. Coronavirus (COVID-19) outbreak: what the department of endoscopy should know. Gastrointest Endosc 2020: S0016-5107(20)30245-5.

143. Gralnek IM, Hassan C, Beilenhoff U, Antonelli G, Ebigbo A, Pellisè $M$, et al. ESGE and ESGENA Position Statement on gastrointestinal endoscopy and the COVID-19 pandemic [published online ahead of print, 2020 Apr 17]. Endoscopy 2020;10.1055/a-1155-6229. doi:10.1055/a-1155-6229.

144. Walsh CM, Fishman DS, Lerner DG. Pediatric Endoscopy in the Era of Coronavirus Disease 2019: A North American Society for Pediatric 
Gastroenterology, Hepatology, and Nutrition Position Paper. J Pediatr Gastroenterol Nutr 2020 Apr 14. doi: 10.1097/MPG. 0000000000002750. Epub ahead of print. PMID 32304561

145. CDC. Recommended Guidance for Extended Use and Limited Reuse of N95 Filtering Facepiece Respirators in Healthcare Settings. 2020 . https//www.cdc.gov/niosh/topics/ hcwcontrols/recommendedguidanceextuse.html. Accessed April 10, 2020.

146. Joob B, Wiwanitkit V. COVID-19 can present with a rash and be mistaken for dengue. $J A m$ Acad. Dermatol. 2020;82(May (5)):e177. doi: 10.1016/j.jaad.2020.03.036. Epub 2020 Mar 22.

147. Jimenez-Cauhe J., Ortega-Quijano D., PrietoBarrios M., Moreno-Arrones Om, FernandezNieto D. Reply to "COVID-19 can present with a rash and be mistaken for Dengue": petechial rash in a patient with COVID-19 infection. $J$ Am. Acad. Dermatol 2020;(April 10) doi: 10.1016/j.jaad.2020.04.016. pii: S01909622(20)30556-9.

148. Guo Y.R., Cao Q.D., Hong Z.S., Tan Y.Y., Chen S.D., Jin H.J. et al. The origin, transmission and clinical therapies on coronavirus disease 2019 (COVID-19) outbreak-an update on the status. Mil Med Res 2020;13(March (1)):11.

149. Han Y, Yang H. The transmission and diagnosis of 2019 novel coronavirus infection disease (COVID-19): a Chinese perspective. J Med Virol 2020;6(March) doi: 10.1002/jmv.25749.

150. Recalcati S. Cutaneous manifestations in COVID-19: a first perspective. J Eur Acad Dermatol. enereol 2020;(March 26) doi: 10.1111/jdv.16387.

151. Zhai P, Ding Y, Wu X, Long J, Zhong Y, Li Y. The epidemiology, diagnosis and treatment of COVID-19. Int $J$ Antimicrob Agents. 2020;28(March):105955.

doi: 10.1016/j.ijantimicag.2020.105955.

152. Manalo I.F., Smith M.K., Cheeley J., Jacobs R. A dermatologic manifestation of COVID-19: transient livedo reticularis. J Am Acad Dermatol 2020;(April 10) doi: 10.1016/j.jaad.2020.04.018.

153. Zhang Y, Cao W, Xiao M. Clinical and coagulation characteristics of 7 patients with critical COVID-2019 pneumonia and acroischemia. Zhonghua Xue Ye Xue Za Zhi. 2020; $41 \quad(\operatorname{March}(0)): E 006 . \quad$ doi: 10.3760/cma.j.issn.0253-2727.2020.0006.

154. Hunt M, Koziatek C. A case of COVID-19 pneumonia in a young male with full body rash as a presenting symptom. Clin Pract Cases Emerg Med 2020; (March 28) doi: 10.5811/cpcem.2020.3.47349.

155. Mahé A., Birckel E., Krieger S., Merklen C., Bottlaender L. A distinctive skin rash associated with Coronavirus Disease 2019? J. Eur. Acad.
Dermatol. Venereol. 2020;(April 15) doi: $10.1111 / j d v .16471$

156. Battegay R., Itin C., Itin P. Dermatological signs and symptoms of measles: a prospective case series and comparison with the literature. Dermatology 2012; 224(1):1-4. doi: 10.1159/000335091. Epub 2012 Jan 10.

157. Basetti S., Hodgson J., Rawson T.M., Majeed A. Scarlet fever: a guide for general practitioners. London J Prim. Care (Abingdon) 2017;9(August (5)):77-79.

doi: 10.1080/17571472.2017.1365677.

158. Gianotti R. COVID 19 and the skin-heuristic review. DermoSprint. 2020 April 06. In press.

159. Magro C., Mulvey J., Berlin D., Nuovo G., Salvatore S., Harp J., Baxter-Stoltzfus A., Laurence J. Complementary associated microvascular injury and thrombosis in the pathogenesis of severe COVID-19 infection: a report of five cases. Transl. Res. 2020 In press.

160. Ahmad I,Rathore FA. Neurological manifestations and complications of COVID-19: A literature review. Journal of Clinical Neuroscience 2020 ;Article in press: Available online 6 May 2020

161. Asadi-Pooya AA, Simani L. Central Nervous System Manifestations of COVID-19: A Systematic Review. J Neurol Sci. 2020 Jun 15;413:116832.

162. Montalvan V, Lee J, Bueso T, De Toledo J, Rivas K. Neurological Manifestations of COVID-19 and Other Coronavirus Infections: A Systematic Review. Clin Neurol Neurosurg 2020 May 15; 194:105921.

163. Patrì A, Fabbrocini G. Hydroxychloroquine and ivermectin: A synergistic combination for COVID-19 chemoprophylaxis and treatment?. $J$ Am Acad Dermatol. 2020;82(6):e221.

164. Covid-19 Mohp protocol ;Version 1.4/30 th May 2020.

165. https://www.accessdata.fda.gov/drugsatfda_docs /label/2009/050742s0261bl.pdf .

166. COVID-19 Treatment Guidelines Panel. Coronavirus Disease 2019 (COVID-19) Treatment Guidelines. National Institutes of Health. Available at https://www.covid19treatmentguidelines.nih.g ov/.

167. Perrin R, Riste L, Hann M, Walther A, Mukherjee A, Heald A. Into the looking glass: Post-viral syndrome post COVID-19. Med Hypotheses. 2020 Nov;144:110055. doi: 10.1016/j.mehy.2020.110055. Epub 2020 Jun 27. PMCID: PMC7320866.

168. George PM, Wells AU, Jenkins RG. Pulmonary fibrosis and COVID-19: the potential role for antifibrotic therapy. Lancet Respir Med. 2020 May 15:S2213-2600(20)30225-3. doi: 10.1016/S2213-2600(20)30225-3. Epub ahead of print. PMID: 32422178; PMCID: PMC7228727. 


\section{Algorithm for Healthcare Providers}

Healthcare provider exposed to suspected or confirmed COVID-19 cases

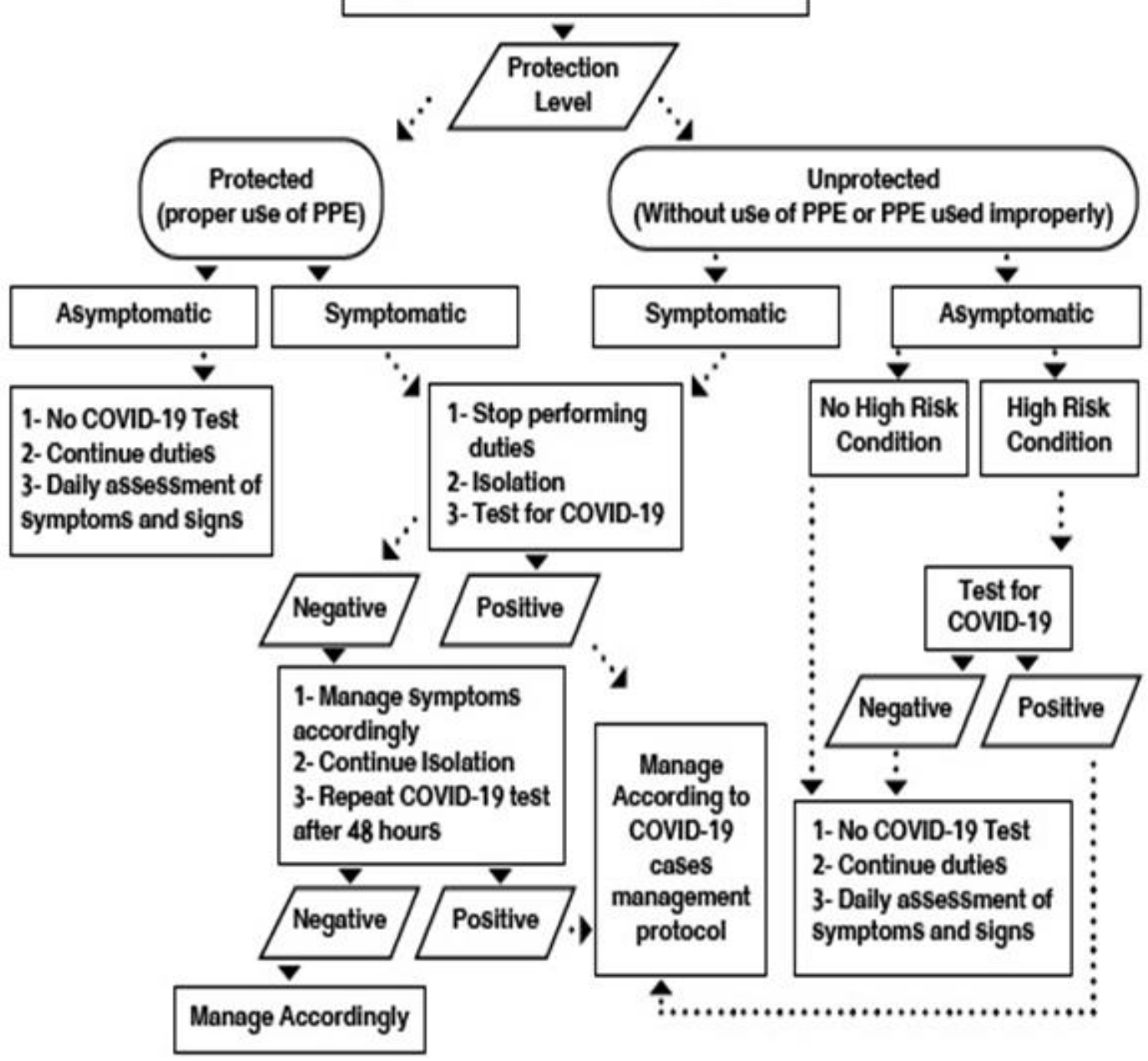

Figure 5: Algorithm for Medical Team by Ministry of Health and Population, Egypt 